\title{
Indigenous peoples and REDD+ safeguards: rights as resistance or as disciplinary inclusion in the green economy?
}

\author{
Julia Dehm* \\ Postdoctoral Fellow at the Rapoport Center for Human Rights and Justice, University of \\ Texas School of Law, USA
}

This article critically evaluates the discourses concerning the social impacts of Reducing Emission from Deforestation and Forest Degradation (REDD+) carbon offset schemes on people living in and around forest areas. In particular, the article critically evaluates two of the strategies proposed to mitigate potential social risks from REDD+ and to promote benefits to forest peoples and indigenous peoples: tenure reform and processes of free, prior and informed consent (FPIC). The article suggests that these strategies may not lead to the outcomes forest peoples and their advocates are seeking and provide only constrained tools for contesting $R E D D+$ projects. This article suggests these strategies may instead operate to facilitate the greater disciplinary inclusion of forest peoples in the so-called 'green economy'.

Keywords: REDD+, carbon offsets, indigenous peoples, tenure reform, forests, UNFCCC

\section{INTRODUCTION}

The social impacts of the Reducing Emissions from Deforestation and Forest Degradation (REDD+) carbon offset scheme ${ }^{1}$ have been an acute concern for peoples

* jdehm@law.utexas.edu. Many thanks to Karen Engle, Anna Grear, Stephen Humphreys, Adil Hasan Khan and Margaret A Young and the anonymous referee for helpful comments on earlier versions of this article and the thesis on which it is based. All errors, of course, remain my own.

1. I use the term 'REDD+' throughout this article (unless directly quoting someone using a different term). When first proposed in 2005 this scheme was initially referred to as RED (Reducing Emissions from Deforestation). It was subsequently known as REDD, Reducing Emissions from Deforestation in Developing Countries or Reducing Emissions from Deforestation and Forest Degradation. The '+' on the end of the 'REDD+' refers to the additional components, beyond reducing emissions from deforestation and reducing emissions from forest degradation, namely the conservation of forest carbon stocks, sustainable management of forests and enhancement of forest carbon stocks that were endorsed in the Cancun Agreements (Decision 1/CP16, 'The Cancun Agreements: Outcome of the Work of the Ad Hoc Working Group on Long-term Cooperative Action Under the Convention' FCCC/CP/2010/7/Add.1 (15 March 2011), para 70). Pursuant to this agreement these activities should receive as much emphasis as reducing emissions from deforestation and reducing emissions from forest degradation. This article analyses and engages with REDD+ as a market-based carbon 'offset' scheme, although a formal decision of funding for REDD+ has not yet been made. This methodological decision is based on analysis, that REDD+ has effectively become a market-based 
living in and around forest areas, project implementation agencies and organizations, non-governmental organizations and other actors. This has sparked intense debates about the social impact of REDD+ projects on 350 million people and about 60 million indigenous peoples who are almost wholly dependent on forests, and the 1.6 billion people who depend to varying degrees on forests for their livelihoods. ${ }^{2}$ These discussions addressing the social impacts of REDD+ schemes on forest peoples have taken place in various forums, including the United Nations Framework Convention on Climate Change (UNFCCC), the Permanent Forum on Indigenous Issues (PFII), the UN-REDD Programme, and the World Bank's Forest Carbon Partnership Facility (FCPF) to name but a few. This article maps these debates and identifies how in discussions about social impacts of REDD+ schemes the question of whether such projects are desirable has been increasingly marginalized, with more attention focused on implementation questions and on how to mitigate potential social risks and maximize the potential benefits of such projects for forest peoples. Many of these discussions have converged in stressing the need for the participation of forest communities within REDD+ projects, tenure reform to recognize local title over forested land and finally, especially in the case of indigenous peoples, processes of reaching free, prior and informed consent. The focus of this article is on critically interrogating these strategies designed to address and manage the social impacts of REDD+.

The concern animating this article is that perhaps these strategies that have been strongly pushed by some forest peoples and their advocates may not lead to the outcomes advocates seek and may in fact be contrary to such interests. These strategies have been proposed in response to fears of exclusionary and top-down models of REDD+ implementation that do not recognize or include forest peoples and their interests. My analysis pays attention to the way in which new forms of globalized authority over forest areas in the global South are being articulated through both exclusivist and inclusive REDD+ models. In fact, if REDD+ is understood as reconfiguring authority over forested land in the global South through the establishment of new forms of property in carbon as well as the through new contractual arrangements for the sale and purchase of ecosystem services, this reconfiguration of authority might actually be facilitated by these measures. The analysis in this article therefore pays attention to the adverse impacts REDD+ may have on forest communities through processes of expulsion and exclusion but also in how REDD+ could potentially facilitate a greater disciplinary inclusion of forest peoples into the new so-called 'green economy'. 3 This article therefore examines how in REDD+ implementation, tenure reform and the process of consultation towards free, prior and informed consent can be read both as calls for recognition and rights 'from below' but also as

scheme even in the absence of a formal decision to that effect by the UNFCCC Conference of the Parties (COP). A formal decision about REDD+'s funding will not be made until December 2016 at the earliest.

2. Johan Eliasch, Climate Change: Financing Global Forests: The Eliasch Review (Earthscan, 2008), 9.

3. For discussion of the 'green economy' see Kate Wilkinson, 'Payment for "Ecosystem Services" and the "Green Economy": Green-washing or Something New?' (2014) 5(2) Journal of Human Rights and the Environment 168; Jim Thomas, 'RIO+20: Toward a New Green Economy - or a Green-washed Old Economy?', Grist 24 March 2011 <www.grist.org>; Peter Ferguson, 'The Green Economy Agenda: Business as Usual or Transformational Discourse?' (2015) 24(1) Environmental Politics 17; Nicola Bullard and Tadzio Müller, 'Beyond the "Green Economy": System Change, Not Climate Change?' (2012) 55(1) Development 54; Dan Brockington, 'A Radically Conservative Vision? The Challenge of UNEP's Towards a 
mechanisms of responsibilization 'from above' that impose obligations considered by implementation agencies to be necessary for the social feasibility of this scheme.

Section 2 of this article provides a background to the history of how REDD+ has come to be proposed as a climate mitigation strategy. Section 3 considers the various discourses on social risks and potential benefits of REDD+ schemes within the UNFCCC, the United Nations Permanent Forum on Indigenous Issues (UNPFII) and NGO discussions. Section 4 examines how concerns about social risks and the social feasibility of REDD+ projects from an implementation perspective have increasingly converged. Section 5 provides an analysis of safeguards in REDD+ as also facilitating a disciplinary inclusion within the 'green economy'. Sections 6 and 7 examine tenure reform and processes towards free, prior and informed consent (FPIC) respectively, tracing how perhaps the more radical potentials of these processes have been neutralized in REDD+ implementation. In the final substantive section I pose questions about the broader distributive questions raised by REDD+'s inclusion in transnational carbon markets.

\section{BACKGROUND TO REDD+}

The concept of RED (as it was then called) was first proposed as a climate mitigation strategy by Costa Rica and Papua New Guinea at the eleventh Conference of the Parties to the UNFCCC (COP11) in 2005. The Bali Action Plan of 2007 called for consideration to be given to '[p]olicy approaches and positive incentives on issues relating to reducing emissions from deforestation and forest degradation in developing countries; and the role of conservation, sustainable management of forests and enhancement of forest carbon stocks in developing countries' as a mitigation measure. ${ }^{4}$ The Cancun Agreement established a framework for a three-staged implementation process for REDD+ and, critically for this article, outlined a list of environmental and social safeguards that should be 'promoted and supported' in REDD+ implementation. ${ }^{5}$ The most significant agreement on REDD+ is the 'Warsaw Framework on REDD+' adopted in December 2013 at COP19 in Warsaw, Poland. ${ }^{6}$ The Warsaw Framework on REDD+ establishes

Green Economy' (2012) 43(1) Development and Change 409; Joanna Boehnert, 'The Green Economy: Reconceptualising the Natural Commons as Natural Capital' (2016) 10(4) Environmental Communication 395.

4. Decision 1/CP.13 'Bali Action Plan' FCCC/CP/2007/6/Add.1 (14 March 2008), para 1(b) (iii), see also Decision 2/CP.13 'Reducing Emissions from Deforestation in Developing Countries: Approaches to Stimulate Action' FCCC/CP/2007/6/Add.1 (14 March 2008).

5. The Cancun decisions on REDD+ can be found in Decision 1/CP.16 'The Cancun Agreements: Outcome of the Work of the Ad Hoc Working Group on Long-term Cooperative Action under the Convention' FCCC/CP/2010/7/Add.1 (15 March 2011), paras 68-79 and its Annex. 6. The 'Warsaw Framework of REDD+' consists of Decisions 9-15/CP.19, see UNFCCC, Report of the Conference of the Parties on its Nineteenth Session, held in Warsaw from 11 to 23 November 2013. Part 1: Proceedings FCCC/CP/2013/10 (31 January 2014) [44]. These are: Decision 9/CP.19 'Work Programme on Results-Based Finance to Progress the Full Implementation of the Activities Referred to in Decision 1/CP.16, paragraph 70' FCCC/CP/2013/10/ Add.1 (31 January 2014); Decision 10/CP.19 'Coordination of Support for the Implementation of Activities in Relation to Mitigation Actions in the Forest Sector by Developing Countries, Including Institutional Arrangements' FCCC/CP/2013/10/Add.1 (31 January 2014); Decision 11/CP.19 'Modalities for National Forest Monitoring Systems' FCCC/CP/2013/10/Add.1 (31 January 2014); Decision 12/CP.19 'The Timing and the Frequency of Presentations of the Summary of Information on how all the Safeguards Referred to in Decision 1/CP.16, Appendix I, are Being Addressed 
methodological rules for carbon accounting or the measurement, monitoring and reporting of 'result-based actions'. ${ }^{7}$ No formal decision has yet been made by the UNFCCC about how REDD+ credits could be incorporated into international carbon markets. However, the carbon accounting framework established by the Warsaw decisions provides the basis for creating an internationally verified and exchangeable carbon offset commodity. REDD+ was confirmed as a key element of the 'Paris Agreement' adopted at COP21 in December $2015 .^{8}$ The Paris Agreement encourages Parties to

take action to implement and support, including through results-based payments, the existing framework as set out in related guidance and decisions already agreed under the Convention for: policy approaches and positive incentives for activities relating to reducing emissions from deforestation and forest degradation, and the role of conservation, sustainable management of forests and enhancement of forest carbon stocks in developing countries; and alternative policy approaches, such as joint mitigation and adaptation approaches for the integral and sustainable management of forests, while reaffirming the importance of incentivizing, as appropriate, non-carbon benefits associated with such approaches. ${ }^{9}$

The stated aim of REDD+ is to "make forests more valuable standing than they would be cut down ${ }^{10}$ by providing economic incentives to address tropical deforestation and forest degradation in the global South through the production of carbon credits from such 'result-based actions' actions. Most controversial is the proposal that such credits could be purchased by countries in the global North as 'offsets' that can be used towards their own international climate mitigation compliance obligations. The dominant rhetoric around REDD+ stresses its potential as a 'win-win-win' solution that brings together the different thematic areas of climate mitigation, biodiversity protection and poverty reduction. ${ }^{11}$

and Respected’ FCCC/CP/2013/10/Add.1 (31 January 2014); Decision 13/CP.19 'Guidelines and Procedures for the Technical Assessment of Submissions from Parties on Proposed Forest Reference Emission Levels and/or Forest Reference Levels' FCCC/CP/2013/10/Add.1 (31 January 2014); Decision 14/CP.19 'Modalities for Measuring, Reporting and Verifying' FCCC/CP/2013/10/ Add.1 (31 January 2014); Decision 15/CP.19 'Addressing the Drivers of Deforestation and Forest Degradation' FCCC/CP/2013/10/Add.1 (31 January 2014).

7. Decision 1/CP.16, para 73 sets out a phased approach for REDD+ that evolves towards 'result-based actions'.

8. 'Paris Agreement' Annex to Decision 1/CP.21 'Adoption of the Paris Agreement' FCCC/ CP/2015/10/Add.1 (29 January 2016), Article 5.

9. Paris Agreement, Article 5(2). Three minor COP decisions at Paris complete the current work programme on REDD+: Decision 16/CP.21 'Alternative Policy Approaches, Such as Joint Mitigation and Adaptation Approaches for the Integral and Sustainable Management of Forests', FCCC/CP/ 2015/10/Add.1 (29 January 2016); Decision 17/CP.21 'Further Guidance on Ensuring Transparency, Consistency, Comprehensiveness and Effectiveness When Informing on How All the Safeguards Referred to in Decision 1/CP.16, Appendix I, are being Addressed and Respected' FCCC/CP/ 2015/10/Add.1 (29 January 2016); Decision 18/CP.21 'Methodological Issues Related to NonCarbon Benefits Resulting from the Implementation of the Activities Referred to in Decision 1/ CP.16, Paragraph 70' FCCC/CP/2015/10/Add.1 (29 January 2016).

10. UN-REDD Programme, Frequently Asked Questions and Answers - The UN-REDD Programme and REDD+, November 2010, <http://www.unep.org/forests/Portals/142/docs/ UN-REDD\%20FAQs\%20\%5B11.10\%5D.pdf>.

11. See for example the speech given by Christiana Figueres, Executive Secretary of the United Nations Framework Convention on Climate Change (UNFCCC) at the Forest Day side event at the 17th Conference of the Parties (COP) in Durban in December 2011, transcribed by the author from 
However, the inclusion of REDD+ within the UNFCCC, and especially its inclusion as a carbon offset mechanism, has been strongly contested, predominately by the "climate justice' movement, which has questioned both the environmental integrity and the social justice of such carbon offsetting regimes. ${ }^{12}$ Critical voices have highlighted how 'green' carbon offsets are fundamentally different from 'brown' carbon and have emphasized the problems in assuming commensurability or 'like for like' for essentially different metabolic interactions. ${ }^{13}$ Critics have highlighted the impossibility of ensuring the 'permanence' of forest carbon sequestration given persistent risks of forest fires, climate-induced ecosystem impacts and illegal logging. ${ }^{14}$ Scholars have problematized the counterfactual assumptions 'additionality' is based upon ${ }^{15}$ and the impossibility of preventing 'leakage' if carbon mitigation does not have universal coverage and no demand-side measures are taken. Critics have also alleged that REDD+ fails to address the key drivers of deforestation, including agribusiness, pulp and paper plantations, palm oil development and mining, and that REDD+ fails to provide the structural incentives to address extensive unsustainable forest and land use. ${ }^{16}$ Concerns have also been raised about the ways in which carbon markets, and particularly the use of offsets, operate as a 'dangerous distraction' ${ }^{17}$ from urgently necessary structural changes in energy production use and distribution, ${ }^{18}$ thereby facilitating 'carbon lock-in'. ${ }^{19}$

CIFOR, 'Closing Remarks - Forest Day 5, 2011'<http://blog.cifor.org/5782/countries-draft-\% E2\%80\%9Cglobal-business-plan \%E2\%80\%9D-for-planet-at-climate-summit-figueres-says/>. On co-benefits see also David Brown, Frances Seymour and Leo Peskett, 'How Do We Achieve REDD Co-benefits and Avoid Doing Harm?' in Arild Angelsen (ed), Moving Ahead with REDD: Issues, Options and Implications (CIFOR, 2008).

12. Larry Lohmann, 'Carbon Trading: A Critical Conversation on Climate Change, Privitization and Power' (The Dag Hammarskjöld Centre, 2006); Steffen Böhm and Siddhartha Dabhi (eds), Upsetting the Offset: The Political Economy of Carbon Markets (MayFlyBooks, 2009); Sarah-Jane Clifton, 'A Dangerous Obsession: The Evidence Against Carbon Trading and for Real Solutions to Avoid a Climate Crunch' (Friends of the Earth, England, Wales and Northern Ireland, 2009); Ronnie Hall, 'REDD Myths: A Critical Review of Proposed Mechanisms to Reduce Emissions from Deforestation and Degradation in Developing Countries' (Friends of the Earth International, 2008); Rebecca Pearse and Julia Dehm, 'In the REDD: Australia's Carbon Offset Project in Central Kalimantan' (Friends of the Earth International 2011); Ashley Dawson, 'Climate Justice: The Emerging Movement Against Green Capitalism' (2010) 109(2) South Atlantic Quarterly 313; and Naomi Klein, This Changes Everything: Capitalism vs. the Climate (Simon \& Schuster, 2014).

13. Rebecca Pearse and Steffen Böhm, 'Ten Reasons Why Carbon Markets Will Not Bring About Radical Emissions Reduction' (2014) 5(4) Carbon Management 325, 332.

14. “"Wild Money": The Human Rights Consequences of Illegal Logging and Corruption in Indonesia's Forestry Sector' (Human Rights Watch, 2009) and Adianto P. Simamora, 'Illegal Logging "Must End" Before REDD takes Effect', The Jakarta Post 13 April $2010<\mathrm{http} / / /$ www.thejakartapost.com/news/2010/04/10/illegal-logging-\%E2\%80\%98must-end\%E2\%80\% 99-redd-takes-effect.html>.

15. In relation to the CDM see Lambert Schneider, 'Assessing the Additionality of CDM Projects: Practical Experiences and Lessons Learned’ (2009) 9 Climate Policy 242.

16. Pearse and Dehm, above (n 12) 14.

17. Simon Bullock, Mike Childs and Tom Picken, 'A Dangerous Distraction: Why Offsetting is Failing the Climate and People: The Evidence' (Friends of the Earth England, Wales and Northern Ireland, 2009).

18. See for example Hall, 2008, above (n 12); Lohmann, 2006, above (n 12); Tamra Gilbertson and Oscar Reyes, 'Carbon Trading: How It Works and Why It Fails' (Dag Hammarskjöld Foundation, 2009).

19. See for example Gregory C Unruh, 'Understanding Carbon Lock-In' (2000) 28 Energy Policy 817. 
Central to debates on REDD+ has been the question of the social impact of such schemes on people who live in and around forested areas, many of whom identify as indigenous, and who depend on forests in varying degrees for their livelihoods. ${ }^{20}$ When REDD+ was first proposed, indigenous peoples, forest-dependent communities and civil society groups immediately articulated serious concerns about REDD+'s potentially harmful social effects. These included the risk that those living in and around forested areas would be dispossessed from their land if REDD+ promoted a global 'land grab' for carbon sequestration. ${ }^{21}$ These concerns are acute given that in many forested countries national governments claim ownership rights over forest lands, disregarding the people living there. There is a long history of natural resource extraction disenfranchising indigenous and other forests peoples. Recent empirical analysis by the Rights and Resources Initiative (RRI) of concessions (across oil, gas, mining agriculture and timber) in eight out of ten 'frontier countries' found that 93-99 per cent of concessions granted were over inhabited land. The RRI analysis speaks to the 'statistical improbability of "clean" (i.e., uninhabited) concession areas' and the nature of property arrangements in 'emerging or frontier markets' which they characterize as 'dysfunctional to the point that ownership of land can be granted to an operator without the tens of thousands of people who live on or depend on that land knowing about it'. ${ }^{22}$ For some commentators, REDD+ schemes represent a form of 'green grabbing', 'the appropriation of land and resources for environmental ends' that has been recognized as 'an emerging process of deep and growing significance'. ${ }^{23}$ The Indigenous Environment Network, for example, has described REDD+ as a form of neo-colonialism or ' $\mathrm{CO}_{2}$ lonialism'. ${ }^{24}$ Most recently, a 'Call to Action to Reject REDD+ and Extractive Industries to Confront Capitalism and Defend Life and Territories' was signed by over 100 civil society groups at the Lima COP. Signatories "reaffirm that rejecting REDD+ and "environmental services", two manifestations of the so called "green economy", is a central part of our struggle against capitalism and extractive industries and the defense of territories, life and Mother Earth'. ${ }^{25}$

Yet, other groups and commentators argue that REDD+ schemes could deliver very different outcomes. ${ }^{26}$ Numerous reports have been published demonstrating

20. Eliasch, above (n 2), 9.

21. See Tom Griffiths, 'Seeing "RED”? "Avoided Deforestation", and the Rights of Indigenous and Local Communities' (Forest Peoples Programme, June 2007).

22. Andrea Alforte et al., 'Communities as Counterparties: Preliminary Review of Concessions and Conflict in Emerging and Frontier Market Concessions' (Rights and Resources Iniatitive 2014) $<$ http://www.rightsandresources.org/wp-content/uploads/Communities-asCounterparties-FINAL_Oct-21.pdf $>, 1$.

23. See James Fairhead, Melissa Leach and Ian Scoones, 'Green Grabbing: A New Appropriation of Nature?' (2012) 39(2) Journal of Peasant Studies 237, 238.

24. Indigenous Environment Network, 'REDD: Reaping Profits from Evictions, Land Grabs, Deforestation and Destruction of Biodiversity' (Indigneous Enviornment Network, 2009) $<$ http://www.ienearth.org/REDD/index.html\#36> and Indigenous Environment Network, 'No to $\mathrm{CO}_{2}$ lonialism! Indigenous Peoples' Guide: False Solutions to Climate Change' (2009) $<$ http://www.uky.edu/ tmute2/nature-society/password-protect/nature-society-pdfs/IndigenousPeoples-Guide-Env.pdf $>$.

25. Call to Action to Reject REDD+ and Extractive Industries; To Confront Capitalism and Defend Life and Territories (December 2014) <http://wrm.org.uy/wp-content/uploads/2014/11/ Call-COP-Lima_NoREDD.pdf>.

26. See for example, 'Press Release: New Research Warns of Unprecedented "Carbon Grab"; Potentially Worse Than Ongoing "Land Grab" - As UN, World Bank Prepare for Carbon 
clear failings of REDD+ projects 'on the ground'. ${ }^{27}$ Nonetheless, despite these documented failings, the question of how REDD+ can be made to 'work' or how it can be 'redeemed' continues to animate discussions. ${ }^{28}$ It is to those discussions of REDD+ projects as both presenting social risks but also potential benefits that we now turn.

\section{DISCOURSES ON SOCIAL RISKS AND POTENTIAL BENEFITS}

This section maps a brief history of the debates over the social impacts of REDD+ schemes. It analyses how these questions of potential social impacts of REDD+ schemes were initially marginalized and excluded from UNFCCC processes, to the present situation where, as Signe Howell notes, "what was listed in the original REDD documents as one of several co-benefits to the conservation of tropical forests, namely "governance and rights", is rapidly turning into a major preoccupation'. ${ }^{29}$ This section traces how as social questions have become mainstreamed in REDD+ policy discussions, more radical voices opposed to REDD+ have been marginalized from these policy debates and the focus of policy debates has become how REDD+ should be implemented, thereby obscuring the preliminary question of whether REDD+ should proceed.

\subsection{Debates in the UNFCCC and by environmental NGOs}

The first report to address the potential social impacts of REDD+ was Seeing 'RED'? Forests, Climate Change Mitigation and the Rights of Indigenous Peoples, written by Tom Griffiths for the Forest Peoples' Program and launched to coincide with COP13 (Bali, 2007) ${ }^{30}$ It highlighted that implementing such projects without proper regard for rights and social and livelihood issues could give rise to the following risks:

- renewed and even increased state and 'expert' control over forests

- overzealous government support for anti-people and exclusionary models of forest conservation

- (evictions, expropriation) to protect lucrative forest carbon 'reservoirs'

- unjust targeting of indigenous and marginal peoples as the 'drivers' of deforestation

- violations of customary land and territorial rights

- state and NGO zoning of forest lands without the informed participation of forest dwellers

Trading Under REDD+' (Rights and Resources Initiative, 19 March 2014), <http://rightsandresources.org/en/news/press-release-new-research-warns-of-unprecedented-carbon-grab-potentially-worse-than-ongoing-land-grab-as-un-world-bank-prepare-for-carbon-trading-un/\# . Vxk535MrLsE>.

27. UNPFII, Indigenous People's Rights and Safeguards in Projects Related to Reducing Emissions from Deforestation and Forest Degradation (n 63) [26], see also the discussion in Howell (n 148), Jutta Kill, 'REDD: A Gallery of Conflicts, Contradictions and Lies' (World Rainforest Movement, 2014), as well as Pearse and Dehm, above (n 12).

28. Michael L Brown, Redeeming REDD+: Policies, Incentives, and Social Feasibility for Avoided Deforestation (Routledge and Earthscan 2013).

29. Howell (n 148), 254.

30. Revised and updated versions of this report were released at Poznan COP (2008) and in May 2009. Tom Griffiths, 'Seeing "REDD"? Forests, Climate Change Mitigation and the Rights of Indigenous Peoples', updated version (Forest Peoples' Programme, 2009). 
- unequal imposition of the costs of forest protection on indigenous peoples and local communities

- unequal and abusive community contracts

- land speculation, land grabbing and land conflicts (competing claims on avoided deforestation (AD) compensation)

- corruption and embezzlement of international funds by national elites

- increasing inequality and potential conflict between recipients and non-recipients of AD funds

- potential conflict among indigenous communities (over acceptance or rejection of $\mathrm{AD}$ schemes). ${ }^{31}$

The report argued that any effective policy on forests and climate change mitigation must be 'based on the recognition of rights, respect for the principle of free, prior and informed consent (FPIC) and requirements for progressive forests sector tenure and governance reforms', ${ }^{32}$ otherwise it would perpetuate injustices. At the launch of the World Bank's Forest Carbon Partnership Facility at the Bali COP in $2007^{33}$ the (then) Chair of the United Nations Permanent Forum on Indigenous Peoples (UNPFII), Victoria Tauli-Corpuz, made a strong statement condemning the World Bank's failure to consult properly with indigenous peoples prior to the Facility's launch. ${ }^{34}$ The newly formed ClimateJusticeNow! network also held a protest against 'offsetting' as a 'false solution' and called instead for mitigation measures that focused on reducing consumption, stopping fossil fuel extraction and promoting sustainable family-farming, peoples' food sovereignty and rights-based conservation measures. ${ }^{35}$

By 2008, questions concerning the social impacts and social feasibility of REDD+ had permeated into UNFCCC processes. The report from a June 2008 Subsidiary Body for Scientific and Technological Advice (SBSTA) workshop on methodological issues associated with REDD+ noted that:

Some participants stressed the importance of involving local communities in the sustainable management of forests. It has been shown that training these communities enables them to manage their forest resources on a more sustainable basis.

31. Tom Griffiths, 'Seeing "RED”? "Avoided Deforestation”, and the Rights of Indigenous and Local Communities' (Forest Peoples Programme, June 2007), 1.

32. Tom Griffiths, 'Seeing 'REDD'? Forests, Climate Change Mitigation and the Rights of Indigenous Peoples, Updated Version' (Forest Peoples Programme, 2009), 1.

33. The World Bank's Forest Carbon Partnership Facility (FCPF) was approved by the Bank's Executive Board on 25 September 2007, launched at COP13 in Bali and became operational in June 2008. The FCPF is one of 15 carbon initiatives of which the World Bank is trustee, through its Carbon Finance Unit capitalized at over US\$2.3 billion. The FCPF describes its 'duel objectives' as both 'building capacity for REDD in developing countries in tropical and subtropical regions' and 'testing a program of performance-based incentive payments in some pilot countries, on a relatively small scale, in order to set the stage for a much larger system of positive incentives and financing flows in the future'. At its launch, the aim of the FCPF was explicitly described as 'jump-start(ing) a forest carbon market'. See The World Bank, 'Forest Carbon Partnership Facility Takes Aim at Deforestation' (Press Release, 11 December 2007) and The World Bank, The World Bank Carbon Funds and Facilities <http://www.worldbank. org/en/topic/climatechange/brief/world-bank-carbon-funds-facilities>.

34. Ibid, 43.

35. Climate Justice Now! 'What's Missing From the Climate Talks? Justice!' (Press Release, 14 December 2007) <http://www.climate-justice-now.org/category/events/bali/>. 
It was noted that social implications, particularly for indigenous people and local communities, associated with any system for reducing emissions from deforestation and forest degradation in developing countries should be taken into consideration. ${ }^{36}$

Simultaneously, mobilization around the social implications of REDD+ continued. The 'Accra Briefing' (August 2008) by NGOs stressed the need for the 'recognition and enforcement of customary and territorial land rights' and reference to the United Nations Declaration on the Rights of Indigenous Peoples (UNDRIP) in any REDD+ policy. ${ }^{37}$ More critically, Simone Lovera, Director of the Global Forest Coalition described REDD+ as 'another disaster in the making' and as a 'fairy-tale about a simple solution to climate change'. ${ }^{38}$ In November 2008 a Friends of the Earth International (FoEI) report REDD Myths concluded that if REDD+ increases the value of forests it is 'likely to have extremely detrimental impacts on some of the poorest people in the world' ${ }^{39}$ It argued that REDD+ implementation could potentially displace millions, and that there were no guarantees that indigenous peoples would benefit from its implementation unless secure land rights were ensured. ${ }^{40}$ The Report also cites additional risks of REDD+, including 'conflict between and within communities (especially where land rights are unclear), changes to local power structures and shifts in social and traditional values and behaviours'. ${ }^{41}$ Survival International's The Most Inconvenient Truth of All: Climate Change and Indigenous Peoples (2009) suggested REDD+ could make recognition of land rights more difficult and undermine existing recognition, as well as potentially restricting traditional land use activities. ${ }^{42}$

Alongside this focus on the potential risks REDD+ could present to forest populations emerged a contradictory discourse, possibly in response, that emphasized potential benefits of REDD+ to populations living in and around forest areas. A 2008 report by the Overseas Development Initiative (ODI) canvassed design and policy options for how REDD+ could be made to 'work for the poor'. ${ }^{43}$ They identify reasons beyond the moral arguments for a 'pro-poor' REDD+, including improved long-term project sustainability, reduced risks for investors and buyers, the potential for increased returns or 'niche' market opportunities as well as donor contractual and legal obligations. Their discussion of the opportunities of 'co-benefits' from REDD+ and imperatives to avoid 'doing harm' emphasized the need to address social aspects of REDD+,

36. UNFCCC, Report on the Workshop on Methodological Issues Relating to Reducing Emissions from Deforestation and Forest Degradation in Developing Countries: A Note from the Secretariat FCCC/SBSTA/2008/11 (8 September 2008) [71]-[72].

37. Chris Lang, 'FoEI: Forests Are More than Carbon', REDD-Monitor 29 October 2008 $<$ http://www.redd-monitor.org/2008/10/29/foei-forests-are-more-than-carbon/>.

38. Chris Lang, 'Global Forest Coalition Attacks REDD', REDD-Monitor 6 October 2008 $<$ http://www.redd-monitor.org/2008/10/06/global-forest-coalition-attacks-redd/>.

39. Ronnie Hall, 'REDD Myths: A Critical Review of Proposed Mechanisms to Reduce Emissions from Deforestation and Degradation in Developing Countries' (Friends of the Earth International, 2008).

40. Ibid.

41. Ibid, 16 .

42. 'The Most Inconvenient Truth of All: Climate Change and Indigenous People' (Survival International 2009), 9.

43. Leo Peskett et al., 'Making REDD Work for the Poor' (Poverty Environment Partnership (PEP), 2008) <http://www.odi.org/sites/odi.org.uk/files/odi-assets/publications-opinion-files/ 3451.pdf>. 
highlighting that REDD+ derives 'much of its legitimacy and potential effectiveness from its ability to improve the welfare of the forest-dependent poor and foster development in some of the poorest regions of the world' ${ }^{44}$ Similar conclusions were reached by the influential Eliasch Review released in October 2008 that drew on the FFP analysis to recognize the potential risks that REDD+ could pose to those living in and around forest areas. For Eliasch, participation was key to mitigating these risks, arguing that 'the full participation of forest communities will make reforms more likely to succeed and benefit the poor'. ${ }^{45}$ This emphasis on 'rights-based' or 'propoor' REDD+ has become central to the mandate of the UN-REDD Programme, whose Framework Document articulates a 'human-rights-based approach', 'gender equity', 'environmental sustainability', 'results-based management' and 'capacity development' as the Programme's guiding principles. ${ }^{46}$ At the Programme's launch in September 2008, participation and benefit-sharing were emphasized, with Achim Steiner, UN Under-Secretary-General and UNEP Executive Director, stating that 'REDD must benefit local communities and indigenous peoples as much as it benefits national economies and the global environment. If that is done the prospects are exciting and potentially far reaching'.

The importance of participation was reiterated in Global Witness' Honest Engagement: Transparency and Civil Society Participation in REDD (February 2009) that stressed "enhancing transparency and understanding of the process, and ensuring broad engagement of civil society organizations and indigenous groups, must move to the top of the agenda if REDD is to avoid failure'. ${ }^{47}$ Other civil society reports, such as FERN's An Overview of Selected REDD+ Proposals (November 2008) focused on the centrality of rights as 'crucial to forest conservation' and the imperatives of tenure reform, stressing that without clearly defined property rights REDD+ would fail. ${ }^{48}$ Released in May 2009 the International Institute for Environment and Development (IIED) report Tenure in REDD: Start-point or Afterthought? foregrounded the issues of tenure and forest governance, and emphasized the need to clarify tenure as a precondition for REDD+ implementation to ensure both the equity and effectiveness of REDD+. ${ }^{49}$

A 2009 report by the Center for International Forestry Research (CIFOR) and the International Union for the Conservation of Nature (IUCN) lists potential benefits that REDD+ could generate for people living in and around forest areas, including:

- encouraging government action to secure and formalize land tenure

- generating government revenue which could be directed to social services including health, education and water in forest areas

44. David Brown, Frances Seymour and Leo Peskett, 'How Do We Achieve REDD Co-benefits and Avoid Doing Harm?' in Arild Angelsen (ed), Moving Ahead with REDD: Issues, Options and Implications (CIFOR, 2008), 109.

45. Eliasch, above (n 2), xiii.

46. UN-REDD, 'Framework Document' (FAO, UNDP, UNEP, 20 June 2008 2008) <http:// www.un-redd.org/Portals/15/documents/publications/UN-REDD_FrameworkDocument.pdf>, 7.

47. 'Honest Engagement: Transparency and Civil Society Participation in REDD' (Global Witness, 2008) <http://www.redd-monitor.org/wp-content/uploads/2009/02/redd-transparencyfinal_ed2rev1.pdf>.

48. Kate Dooley, 'An Overview of Selected REDD Proposals' (FERN/Forest Peoples Program, 2008) <http://www.redd-monitor.org/wp-content/uploads/2008/12/document_4314_4315. pdf $>, 10$.

49. Lorenzo Cotula and James Mayers, 'Tenure in REDD - Start-point or Afterthought?' (International Institute for Environment and Development, 2009). 
- the creation of new income streams for forest-dwellers

- positive livelihood benefits of projects which maintain forests' abilities to regulate eco-system services

- maintaining forest ecosystem services may provide a buffer from climaterelated impacts such as reduced agricultural yields. ${ }^{50}$

A further IUCN briefing document noted that REDD+ projects may improve livelihoods and provide opportunities to strengthen the capacity of indigenous peoples' organizations and communities, while an increased awareness of indigenous peoples' role in forest management may contribute to further recognition of indigenous peoples' traditional knowledge systems. It concluded that if rights are recognized, REDD+ is more likely to achieve mitigation and sustainable development objectives. ${ }^{51}$

Two key ways of talking about social impacts therefore increasingly structure and frame the debates: one discourse focuses on the risks REDD+ projects might present to people living in and around forested areas, while emphasizing the need to manage these risks; the other focuses on the benefits REDD+ projects might present to people living in and around forested areas, seeking to realize these benefits. The question then becomes: if these decisions are made in this way, then how can the interests of people living in and around forested areas nonetheless be protected or enhanced? This framing increasingly focuses critique and attention not on REDD+ as a project but rather on its mode of implementation. ${ }^{52}$

\subsection{Debates within the UN Permanent Forum on Indigenous Issues}

The previous section identified debates on the social impacts of REDD+ primarily located in and around the UNFCCC processes. However, there have also been concurrent discussions on these issues in the UN Permanent Forum on Indigenous Issues (UNPFII). In this section, I trace how within this space a similar grammar of argumentation to the one discussed above developed. In the UNPFII debates on the potential social impacts of REDD+, individuals and organizations who voiced positions hostile to REDD+ were sidelined, as the focus of the debate also shifted away from questions of whether or not such projects were desirable to focus on how they should be implemented in order to best manage risks and realize potential benefits. This section briefly outlines debates within and reports to the UNPFII between 2008 and 2013.

'We want to speak' was the collective call from a caucus in the back of the room on 2 May 2008, the concluding day of the Seventh Session of the United Nations Permanent Forum on Indigenous Issues. Initially the Chair of the session, Victoria Tauli-Corpuz, attempted to continue through the agenda, but she was prevented from doing so as the clapping and chanting from the back of the room intensified in speed and volume. Delegates in the two back rows were on their feet calling out: "we want to make a

50. Kathleen Lawlor and David Huberman, 'Reduced Emissions from Deforestation and Forest Degradation (REDD) and Human Rights' in Jessica Campese et al. (eds), Rights-based Approaches: Exploring Issues and Opportunities for Conservation (CIFOR and IUCN, 2009). 51. 'Briefing Document: Indigenous Peoples and Climate Change/REDD: An Overview of Current Discussions and Main Issues' (IUCN, 2010), 9.

52. This argument is made in the context of land grabbing in: Saturnino Borras and Jennifer Franco, 'From Threat to Opportunity? Problems with the Idea of a "Code of Conduct" for LandGrabbing' (2010) 13 Yale Human Rights and Development Law Journal 507. 
statement!', 'you have to listen to us - we want that you hear us', 'Indigenous peoples want to make a statement!' 'Madame Chair - we want to speak'. The Chair offered to give the interjectors the floor once 'business' had been finished, but the protests continued and security personnel were called in to the session. It was only when the situation risked spiralling out of control, with indigenous delegates almost forcefully evicted from the United Nations space that claimed to represent and facilitate their voices, that the Chair requested security staff to leave and reorganized proceedings to allow time to listen to a statement prepared by the Caucus Indigenas de Abya Yala. ${ }^{53}$

The controversy described above was sparked by recommendations that had been presented to the UNPFII on carbon market 'offset' mechanisms including the Clean Development Mechanism (CDM) and REDD+. ${ }^{54}$ One of the recommendations in question described the CDM as a 'good example of the kind of partnership that will become increasingly important ${ }^{55}$ and called for greater engagement with indigenous peoples in processes of designing and implementing such programmes. Another recommendation called on World Bank carbon funds to centrally involve indigenous peoples in their project design, implementation and evaluation. ${ }^{56}$ These recommendations, calling for more indigenous participation and voice in REDD+ projects, ran counter to the opposition to REDD+ articulated by some indigenous groups and their representatives in the UNPFII. Tom Goldtooth, executive director of the Indigenous Environment Network recalls that throughout the seventh session 'intervention after intervention of our Indigenous brothers and sisters from the global South said "this is wrong, we do not support REDD, we do not support these offset initiatives"" ${ }^{57} \mathrm{He}$ recounts that "despite this overwhelming opposition [to carbon trading] we get [a report] from the permanent forum members promoting ... these World Bank initiatives'. ${ }^{58}$

After the commotion subsided, a petition addressed to the UNPFII expressing opposition to REDD+ was read out, which included the assertion that '[ $t$ ]he vast majority of indigenous peoples feel that the REDD will not benefit Indigenous Peoples, but in fact will result in more violations of Indigenous Peoples' rights' ${ }^{59}$ In response, some amendments were made to the recommendations which emphasized

53. See 'REDD "2nd MAY REVOLT" at the UNPFII (REDD, CDM)'<http://www.youtube. $\mathrm{com} /$ watch? $\mathrm{v}=\mathrm{UtORVi7GybY}>$; for the text of the Communique from the Indigenous Environmental Network (IEN) see 'PROTEST: Indigenous Peoples "2nd MAY REVOLT" at the UNPFII (United Nations Permanent Forum on Indigenous Issues)' 12 May 2008, <http:// www.carbontradewatch.org/video/protest-indigenous-peoples-2nd-may-revolt-at-the-unpfii-4. html>.

54. Victoria Tauli-Corpuz and Aqqaluk Lynge, Impact of Climate Change Mitigation Measures on Indigenous Peoples and their Territories and Lands, UNPFII, Seventh Session, E/C.19/2008/10, 20 March 2008.

55. Draft recommendations E/C.19/2008/L.3, para 5, reflected in Economic and Social Council, Permanent Forum on Indigenous Issues: Report on the Seventh Session (21 April-2 May 2008) E/C.19/2008/13, para 8.

56. Ibid [88]. Note, the recommendation also stated that 'Those who opt not to participate in reduction of emissions from deforestation in developing countries or in the Forest Carbon Partnership Facility-supported projects should be respected'.

57. Transcribed by the author from 'REDD "2nd MAY REVOLT" at the UNPFII (REDD, CDM)' <http://www.youtube.com/watch?v=UtORVi7GybY>.

58. Ibid.

59. 'PROTEST: Indigenous Peoples "2nd MAY REVOLT" at the UNPFII (United Nations Permanent Forum on Indigenous Issues)' 12 May 2008, <http://www.carbontradewatch.org/ video/protest-indigenous-peoples-2nd-may-revolt-at-the-unpfii-4.html $>$. 
that the REDD+ and the 'renewed political focus on forests' should be 'used towards securing the rights of indigenous peoples living in forests'. ${ }^{60}$ The amendments also recognized that the "current framework for REDD is not supported by most indigenous peoples' and that all

new proposals for avoided deforestation or reduced emissions from deforestation must address the need for global and national policy reforms and be guided by the United Nations Declaration on the Rights of Indigenous Peoples, respecting rights to land, territories and resources; and the rights of self-determination and the free, prior and informed consent of the indigenous peoples concerned. ${ }^{61}$

Since this incident in 2008, there have been several developments in REDD+ frameworks, including around safeguards, which will be discussed in more detail in the following section. The Cancun Agreements noted the UNDRIP and stated that 'respect for the knowledge and rights of indigenous peoples and local communities' as well as their 'full and effective participation' should be 'promoted and supported'. ${ }^{62}$ Since this incident there have been several reports by Special Rapporteurs appointed by the Forum that have addressed the impacts of carbon-offset mechanisms on indigenous peoples. ${ }^{63}$ The most recent of these, by Sena, Cunningham and Xavier, provides a brief review of the experiences and positions of indigenous organizations and communities around the world in relation to REDD+. It acknowledges

... numerous reported cases of REDD-plus projects involving indigenous communities that appear to have signed highly disadvantageous agreements as a consequence of a lack of understanding of the implications, a lack of access to advice or information, bad faith on the part of the REDD-plus developer and in some cases, a breakdown in community governance arrangements or corruption on the part of local officials. Terms of such purported contracts have included, for example, 'agreements' that the community will cease to use its forests for any production purposes, including subsistence, hunting and gathering activities. Notwithstanding the fact that the community (or certain members of the community

60. See UNPFII 'Permanent Forum Hails General Assembly Adoption of Indigenous Rights Declaration, Pledges to Make it "a Living Document" as Seventh Session Concludes: On Special Theme, Says Indigenous Way of Life Threatened by Climate Change, Calls for Indigenous Participation in All Aspects of International Debate on Issue' (Media Release, 2 May 2008), $<$ http://www.un.org/News/Press/docs/2008/hr4953.doc.htm>.

61. Permanent Forum on Indigenous Issues: Report on the Seventh Session (21 April-2 May 2008), Economic and Social Council, E/2008/43, E/C.19/2008/13 (14 May 2008), [44] and [45]. 62. Decision 1/CP.16, Annex, para 2(c) and (d).

63. These include a report by Victoria Tauli-Corpuz and Lars-Ander Baer, Results of the Copenhagen meeting of the Conference of the Parties to the United Nations Framework Convention on Climate Change; Implications for Indigenous Peoples' Local Adaptation and Mitigation Measures, Permanent Forum on Indigenous Issues, 9th session, E/C.19/2010/18 (2 March 2010); Hassan Id Balkassm and Paimaneh Hasteh, Study on the Extent to which Climate Change Policies and Projects Adhere to the Standards set Forth in the United Nations Declaration on the Rights of Indigenous Peoples: Note by the Secretariat, UNPFII, Ninth Session, E/C.19/ 2010/7 (2 February 2010); see also the concept note prepared as a background for this study: The Extent to which Climate Change Policies and Projects Adhere to the Standards set Forth in the United Nations Declaration on the Rights of Indigenous Peoples: Concept Note Submitted by the Permanent Forum Special Rapporteurs, UNPFII, Eighth Session, E/C.19/2009/5 (25 March 2009) and a survey by Paul Kanyinke Sena, Myrna Cunningham and Bertie Xavier, Indigenous People's Rights and Safeguards in Projects Relating to Reducing Emissions from Deforestation and Forest Degradation, UNPFII, Twelfth session, E/C.19/2013/7 (5 February 2013). 
claiming to act on its behalf) may have signed an agreement, clearly the free, prior informed consent of the community has not been given, nor are the terms mutually agreed by any reasonable definition of the terms. In some cases, the document has been prepared in the language of the developer with no faithfully translated version provided to the community. Such cases have been observed in many regions, including the Amazon and the Congo Basin countries and in the Asia-Pacific region. ${ }^{64}$

The quote above from the UNPFII speaks to critical 'on the ground' realities about how REDD+ is being implemented and the abuses of power evident in some REDD+ schemes, confirming findings of abuses in REDD+ implementation that have been confirmed in other NGO reports. ${ }^{65}$ However, the UNPFII report positions these examples at one end of a spectrum, highlighting also opposite cases 'where the initiative for a project springs from a community decision, perhaps as a way of funding its own previously determined territorial management and community development aspirations'. ${ }^{66}$ The report thereby implies that the problems associated with REDD+ are not inherent to the scheme but are the product of the lack of good governance, information or understanding, or are the product of corruption or bad faith. The report further positions properly implemented REDD+ schemes as an opportunity for indigenous peoples to consolidate rights. ${ }^{67}$ There is therefore - at least at a rhetorical level, but also evidenced in a proliferation of reports on rights in REDD+ and 'best practice' guidelines - a convergence between rights discourses and REDD+ imperatives.

The report also finds that there are 'two different scenarios' or two divergent positions adopted by indigenous groups in relation to REDD+:

(a) Organizations radically oppose REDD-plus owing mainly to insecurity as to the rights of indigenous peoples, the weakness of existing national legal frameworks to protect those rights and the uncertainties of the Framework Convention negotiations on REDD-plus. Those organizations are strongly opposed to the carbon market.

(b) Organizations consider the REDD-plus model as opportunities for indigenous peoples. Although they share reservations about the risks that this model offers if indigenous peoples' rights are not fully recognized and strong safeguards are not in place, some organizations are open to the voluntary carbon market. ${ }^{68}$

Although the report acknowledges many reports of communities signing 'highly disadvantageous agreements', ${ }^{69}$ it engages minimally with the former position, and

64. Paul Kanyinke Sena, Myrna Cunningham and Bertie Xavier, Indigenous People's Rights and Safeguards in Projects Related to Reducing Emissions from Deforestation and Forest Degradation: Note by the Secretariat, UN ESCOR, Permanent Forum on Indigenous Issues, 12th sess, Agenda Item 5, UN Doc E/C.19/2013/7 (5 February 2013) [26].

65. See for example Jutta Kill, 'REDD: A Gallery of Conflicts, Contradictions and Lies' (World Rainforest Movement, 2014), cf. the more optimistic accounts provided in Erin O Sills et al., REDD+ on the Ground: A Case Book of Sub-National Initiatives Across the Globe (Bogar: CIFOR, 2014).

66. Paul Kanyinke Sena, Myrna Cunningham and Bertie Xavier, Indigenous People's Rights and Safeguards in Projects Related to Reducing Emissions from Deforestation and Forest Degradation: Note by the Secretariat, UN ESCOR, Permanent Forum on Indigenous Issues, 12th sess, Agenda Item 5, UN Doc E/C.19/2013/7 (5 February 2013), [25].

67. Ibid [59].

68. Ibid [58].

69. Ibid [24]. 
concludes that 'REDD-plus offers opportunities for indigenous peoples to consolidate their rights, including tenure of their territories and the implementation of communityled livelihood strategies' ${ }^{70}$ The focus of the Report is on 'the nature of potential benefits to indigenous peoples and how those benefits could be secured through the various safeguard mechanisms being developed'. ${ }^{71}$ As in the discussions of safeguards described above, the normative question of whether REDD+ should be implemented is eluded through this focus. Instead, the attention is directed to questions of REDD+'s implementation: how to manage the potential risks of REDD+ and how to promote benefits through REDD+.

\subsection{The gradual elaboration of safeguards}

In the previous sections I have traced how discussions on REDD+ in various forums have increasingly converged around the need for safeguards as a means by which risks can be managed and potential multiple benefits promoted. The road towards safeguards in the UNFCCC was, however, far from smooth. The Poznan (COP14, 2008) SBSTA decision invited parties and observers 'to submit ... their views on issues relating to indigenous people [sic] and local communities for the development and application of methodologies' ${ }^{72}$ This wording was the subject of intense dispute: initial draft wording had also included 'noting the rights and importance of engaging indigenous peoples and other local communities'. However, this reference to 'rights' was removed after lobbying by the United States, Canada, New Zealand and Australia, ${ }^{73}$ a removal which sparked civil society protests ${ }^{74}$ demanding 'that an unequivocal reference to rights and the UN Declaration on the Rights of Indigenous peoples be reinserted into the draft COP14 Decision text on REDD'. ${ }^{75}$ The language also ignored the address to the session by UNPFII Chair Victoria Tauli-Corpuz, who called for the UNDRIP to be the 'overarching framework for the design, methodologies, implementation and monitoring and evolution of REDD+' and that no projects should occur on indigenous lands without free, prior and informed consent. ${ }^{76}$ At the final SBSTA session, a representative from the International Indigenous Peoples' Forum on Climate Change (IIPFCC) sought to speak to express profound disappointment over the removal of 'rights' language and the use of the singular rather

70. Ibid [59].

71. Ibid [summary].

72. SBSTA, Reducing Emissions from Deforestation in Developing Countries: Approaches to Stimulate Action: Draft Conclusions Prepared by the Chair, FCCC/SBSTA/2008/L.23 (10 December 2008) para 11.

73. Australia, New Zealand, Canada and the United States all voted against the United Nations Declaration on the Rights of Indigenous People when it was adopted by the General Assembly on 13 September 2007. However, all four of these settler-colonial states have since endorsed the Declaration: Australia on 3 April 2009, New Zealand on 19 April 2010, Canada on 12 November 2010 and the United States on 16 December 2010.

74. 'Indigenous Peoples Outraged at Removal of Rights in REDD Outcome' Third World Network Poznan News Update 12 (11 December 2008).

75. Chris Lang, 'Rights Struck from Draft Text on REDD', REDD-Monitor 9 December 2008 $<$ http://www.redd-monitor.org/2008/12/09/rights-struck-from-draft-text-on-redd/>.

76. Chris Lang, 'UN Permanent Forum on Indigenous Issues Intervenes on REDD in Poznan', REDD-Monitor 2 December $2008<\mathrm{http} / / / \mathrm{www} . r e d d-m o n i t o r . o r g / 2008 / 12 / 02 /$ unpfiiintervenes-on-redd-in-poznan/>. 
than the collective term 'indigenous peoples' ${ }^{77}$ The Chair prevented her from speaking by saying:

I'm sorry, I'm going to have to stop you there because you [civil society groups] have exceeded the two minutes allocated to you for the statement and in the interests of time we are going to have to move on and close the meeting. ${ }^{78}$

Given that the UNFCCC COP process allows for more civil society participation and inclusion of indigenous voices than many other international legal institutions, ${ }^{79}$ this incident speaks to broader institutional failings to provide space and meaningful participation for diverse and oppositional voices. Moreover, this incident thus calls attention to the limitations of calls for participation and the broader issue of to what extent these institutional spaces are able to hear and take on board such voices, even if they are allowed to speak.

Subsequent to the COP, multiple submissions from Parties and observer groups were received by the SBSTA. ${ }^{80}$ Many submissions received stressed the need to fully involve local communities in monitoring and implementation and the necessity for safeguards and tenure clarification, while many submissions also stressed the necessity of a rights-based approach, including provisions for consultation towards free, prior and informed consent and other rights articulated in the UNDRIP. In doing so, the submissions reflected the emerging consensus in the literature discussed above. At Copenhagen a methodological decision on REDD+ recognized the 'need for full and effective engagement of indigenous peoples and local communities in, and the potential contribution of their knowledge to, monitoring and reporting of activities', ${ }^{81}$ although a separate draft text on safeguards could not be agreed upon. ${ }^{82}$

The Cancun Agreement, as discussed above, listed seven safeguards that should be 'promoted and supported' while also articulating that in preparing national REDD+ strategies or plans countries should ensure 'the full and effective participation of relevant stakeholders, inter alia, indigenous peoples and local communities' ${ }^{83}$

The development and verification of safeguards to ensure environmental integrity and to prevent negative social impacts has been one of the most fraught areas of REDD+ policy. The Cancun Agreement affirmed social and environmental

77. Chris Lang, 'Indigenous Peoples Censored at Poznan', REDD-Monitor 15 December $2008<$ http://www.redd-monitor.org/2008/12/15/indigenous-peoples-censored-at-poznan/>.

78. 'REDD: Indigenous Peoples Not Allowed to Speak at UNFCCC-10 Dec 2008' <http:// www.youtube.com/watch? $=$ brsqUgbBHu0 $>$.

79. See Carola Betzold and Anaïd Flesken, 'Indigenous Peoples in International Environmental Negotiation: Evidence from Biodiversity and Climate Change', in Thoko Kaime (ed), International Climate Law and Policy: Cultural Legitimacy in Adaptation and Mitigation (Routledge, 2014), 63-83.

80. UNFCCC, Issues Relating to Indigenous Peoples and Local Communities for the Development and Application of Methodologies: Submissions from Parties, FCCC/SBSTA/2009/ MISC.1 (10 March 2009), Add.1 (17 April 2009) and Add.2 (27 June 2009).

81. Decision 4/CP.15, preamble.

82. Draft Decision -/CP.15 Policy 'Approaches and Positive Incentives on Issues Relating to Reducing Emissions from Deforestation and Forest Degradation in Developing Countries; and the Role of Conservation, Sustainable Management of Forests and Enhancement of Forest Carbon Sinks in Developing Countries', FCCC/AWGLCA/2009/L.7/Add.6 (15 December 2009). 83. Decision 1/CP.16, para 72. 
safeguards that should be 'promoted and supported' in REDD+ implementation. ${ }^{84}$ These safeguards are:

(a) That actions complement or are consistent with the objectives of national forest programmes and relevant international conventions and agreements;

(b) Transparent and effective national forest governance structures, taking into account national legislation and sovereignty;

(c) Respect for the knowledge and rights of indigenous peoples and members of local communities, by taking into account relevant international obligations, national circumstances and laws, and noting that the United Nations General Assembly has adopted the United Nations Declaration on the Rights of Indigenous Peoples;

(d) The full and effective participation of relevant stakeholders, in particular indigenous peoples and local communities;

(e) That actions are consistent with the conservation of natural forests and biological diversity, ensuring that the actions referred to in paragraph 70 of this decision are not used for the conversion of natural forests, but are instead used to incentivize the protection and conservation of natural forests and their ecosystem services, and to enhance other social and environmental benefits;

(f) Actions to address the risks of reversals;

(g) Actions to reduce displacement of emissions. ${ }^{85}$

At Durban it was agreed that REDD+ host countries should provide a summary of information to the COP on how such safeguards are being 'addressed and respected'. ${ }^{86}$ The Warsaw Framework invites parties to provide such summaries to the UNFCCC REDD+ web platform. ${ }^{87}$ The Warsaw decision on results-based finance provides that 'developing countries seeking to obtain and receive results-based payments ... should provide the most recent summary of information on how all the safeguards ... have been addressed and respected' ${ }^{88}$ However, unlike the carbon accounting aspects of the framework, this information is not subject to international technical review. While the EU proposed a scheme of indicators for the achievement of safeguards, this was ultimately rejected due to concerns about costs and sovereignty. ${ }^{89}$

84. Decision 1/CP.16, para 69. The language of 'promoted and supported' in relation to the safeguards is criticized by environmental and social justice groups as 'too weak' to ensure safeguards are enforced. Note that in the draft Copenhagen text the words 'promoted and supported' in relation to the safeguards were still bracketed text as they were highly contentious (the preCopenhagen draft used the strong language of 'shall implement'), these brackets have been removed in the Cancun text. Article 71(d) simply requests that countries develop a 'system for providing information on how the safeguards referred to in annex 1 are being addressed and respected'. The pre-Cancun draft text called for 'a system for monitoring and informing the Convention on how the safeguards referred to in Annex II ... are being addressed and respected ...'. An entry on REDD-Monitor alleges it was PNG who proposed the weakened wording on safeguard monitoring. Chris Lang, 'How Kevin Conrad Dismissed NGO Requests Not to Weaken Safeguards in the REDD Text in Cancun', REDD-Monitor 5 January 2011 $<$ http://www.redd-monitor.org/2011/01/05/how-kevin-conrad-dismissed-ngo-requests-not-toweaken-safeguards-in-the-redd-text-in-cancun/>.

85. Decision 1/CP.16, Annex, para 2.

86. Decision 12/CP.17, para 3.

87. Decision $12 / \mathrm{CP} .19$, para 3 .

88. Decision $9 /$ CP.19, para 4.

89. Maria Eugenia Recio, 'The Warsaw Framework and the Future of REDD+' (2014) 24(1) Yearbook of International Environmental Law 37. 
The fact that these safeguards are not internationally enforceable or verifiable has been the subject of significant criticism. ${ }^{90}$ While the safeguards, as expressed in UNFCCC agreements on REDD+, lack a legally enforceable mechanism, they nonetheless have a normative impact in that their language, style and approach is reflected in social and environmental safeguard provisions that have been adopted by other agencies involved in REDD+-readiness or the regulation of carbon markets in more tangible ways. Several guides have been prepared on how to actualize safeguards within national REDD+ projects. ${ }^{91}$

Although it remains an assumption in the REDD+ literature that 'host' governments of REDD+ projects should develop capacity to implement and enforce safeguards ${ }^{92}$ as part of 'REDD+-readiness' programmes, discussions on safeguards in host countries are described as being 'in their infancy'. ${ }^{93}$ The implementation of safeguards within the sovereign/citizen model of 'rights' is seen as representing 'only a minor component of the overall REDD+ policy dialogue' ${ }^{94}$ REDD+ safeguards are taking place within an emerging transnational governance network that includes the internal guidelines and procedures governing donors' activities (such as international development agencies of countries including Australia, Norway and Germany and multilateral development banks) and policies or voluntary Codes of Conduct of implementing agencies (transnational conservation or aid bodies such as The Nature Conservancy, Flora and Fauna International, the World Wide Fund for Nature, Wetlands International, BOS or CARE) alongside market-based certification schemes. A key voluntary certification scheme is the REDD+ Social and Environmental Standards (Version 2, 2012) ${ }^{95}$ developed by way of 'stakeholder' consultation where CARE International and the Climate, Community and Biodiversity Alliance (CCBA) serve as the Secretariat. Conservation organizations too have been under sustained pressure to adopt Codes of Conduct. The 'Durban Action Plan' confirmed at the 5th World Parks Congress in 2003 by the IUCN $^{96}$ is an example of how this promotion of 'rights-based approaches' 97 to conservation is expressed by major conservation NGOs. ${ }^{98}$ Strategic advocacy by NGOs has

90. See for example, Chris Lang, 'REDD Safeguards: What Are They?', REDD-Monitor 20 March 2015.

91. Daniela Rey and Steve Swan, 'A Country-Led Safeguards Approach: Guidelines for National REDD+ Programmes' (SNV - The Netherlands Development Organisation, REDD+ Programme, 2014); Florence Daviet and Gaia Larsen, 'Safeguarding Forests and People: A Framework for Designing a National System to Implement REDD+ Safeguards' (World Resources Institute, 2012), see also D Ray et al., 'A Guide to Understanding and Implementing the UNFCCC REDD+ Safeguards' (Client Earth, 2013).

92. See for example, Pillar Five of Indonesia REDD+ Strategy, 'REDD+ National Strategy' (Indonesian REDD+ Task Force, 2012) <www.satgasreddplus.org $>$ on the inclusion of stakeholders.

93. David M Mwayafu and James W Kisekka, 'Promoting and Implementing REDD+ Safeguards at a National Level in East Africa' (REDD.net, 2012) <http://theredddesk.org/resources/ promoting-and-implementing-redd-safeguards-national-level-east-africa $>1$.

94. Ibid.

95. REDD+ Social and Environmental Standards, Version 2 (10 September 2012).

96. IUCN World Parks Congress, 'Durban Action Plan' (Revised Version, March 2004), $<$ http://cmsdata.iucn.org/downloads/durbanactionen.pdf >.

97. Thomas Greiber et al., 'Conservation with Justice: A Rights-based Approach' (IUCN 2009). 98. Jessica Campese, 'Rights-based Approaches to Conservation: An Overview of Concepts and Questions', in Jessica Campese et al. (eds), Rights-based Approaches: Exploring Issues and Opportunities for Conservation (CIFOR and IUCN, 2009). 
focused on holding REDD+ funders to their own internal standards. ${ }^{99}$ In this policy space, a voluntary commitment to FPIC has 'come to be appreciated as a crucial tool in the achievement of social and environmental sustainability'. ${ }^{100}$

Moreover, there has been, as Margaret Young argues, a 'plethora of informal or soft-law processes which have developed outside of the UNFCCC negotiations but which influence and draw upon these negotiations', ${ }^{101}$ predominately arising out of bilateral and multilateral processes engaged in supporting REDD+-readiness activities. The Forest Carbon Partnership Facility (FCPF) has developed a 'Common Approach to Social and Environmental Safeguards for Multiple Delivery Partners under the Forest Carbon Partnership Facility Readiness Fund' ('Common Approach'). ${ }^{102}$ It sets out terms of reference for Strategic and Environmental Social Assessment (SESA) and Environmental and Social Management Frameworks (ESMFs) based upon the World Bank safeguards. At the time of writing, new safeguards were in the process of being developed and a revised (second) draft had just been released. Human rights advocates have argued that these proposed policies will 'vastly weaken protections for affected communities and the environment'. ${ }^{103}$ In collaboration with UN-REDD, the FCPF has produced 'Guidelines on Stakeholder Engagement in REDD+ Readiness with a focus on the Participation of Indigenous Peoples and Other Forest-Dependant Communities' ${ }^{104}$ The UN-REDD Programme has additionally produced 'Guidelines on Free, Prior and Informed Consent'. ${ }^{105}$

These safeguarding mechanisms are key sites through which REDD+ interacts with other regimes. ${ }^{106}$ Feja Lesniewska argues that 'since Cancun, safeguards have been seen as the opportunity through which the interaction between these different law making processes could be more formally co-ordinated'. ${ }^{107}$ Safeguards operate as a 'missing link' that connects REDD+ with other fields of law; they 'provide formal justification [for] the increasing cross-fertilization and collaboration between forest law and governance processes beyond the UNFCCC' ${ }^{108}$ These policies are also

99. 'Preliminary Study on the Safeguards Policies of Bilateral Donors to REDD Programs in Indonesia' (HuMa, 2010).

100. Marcus Colchester and Maurizio Farhan Ferrari, 'Making FPIC Work: Challenges and Prospects for Indigenous Peoples' (Forest Peoples Programme, 2007), 2.

101. Margaret A Young, 'REDD+ and Interacting Legal Regimes', in Christina Voigt (ed), Research Handbook on REDD-plus and International Law (Edward Elgar, 2016).

102. Forest Carbon Partnership Facility (FCPF) Readiness Fund, Common Approach to Environmental and Social Safeguards for Multiple Delivery Partners, 9 June 2011, rev. 10 August 2011, $<$ http://www.forestcarbonpartnership.org/sites/forestcarbonpartnership.org/files/Documents/PDF/ Nov2011/FCPF\%20Readiness\%20Fund\%20Common\%20Approach\%20_Final_\%2010-Aug2011_Revised.pdf>.

103. 'World Bank: Dangerous Rollback in Environmental and Social Protections' Human Rights Watch, 4 August 2015, <https://www.hrw.org/news/2015/08/04/world-bank-dangerous-rollback-environmental-social-protections $>$.

104. UN-REDD Programme and Forest Carbon Partnership Facility (FCPF), Guidelines on Stakeholder Engagement in REDD+ Readiness with a Focus on the Participation of Indigenous Peoples and Other Forest-Dependent Communities, 20 April 2012, <http://www.un-redd.org/ Stakeholder_Engagement/Guidelines_On_Stakeholder_Engagement/tabid/55619/Default.asp $>$. 105. UN-REDD Programme, Guidelines on Free, Prior and Informed Consent and Legal Companion (January 2013).

106. See Young, 2016, above (n 101).

107. Feja Lesniewska, 'UNFCCC REDD+ COP Decisions: The Cumulative Effect on Forest Related Law Processes' (2013) 15 International Community Law Review 103, 121.

108. Ibid, 119-120. 
key sites of intersection between REDD+ and other World Bank 'developmental' interventions such as 'good governance' promotion and land tenure formalization that have long and contentious histories. ${ }^{109}$ The promotion of safeguards has therefore in many ways also operated to expand the sphere of authorized intervention by international financial institutions (IFIs) and other bilateral and multilateral bodies into the lives of those who live in and around forested areas.

\section{MANAGING SOCIAL RISKS: ENSURING SOCIAL FEASIBILITY}

In this section, I highlight further mutation in the discourse on potential risks and benefits of REDD+, namely the way in which the same language is taken up to describe risks and benefits to the project itself, its implementing agency or its investors. That is, discussions on 'social' questions surrounding REDD+ were increasingly extended beyond an analysis of such a project's potential impacts for affected forest communities, to encompass the way social conflict might also present risks to REDD+ projects themselves. In this way the 'social' question in relation to REDD+ increasingly refers to a 'problem space' constituted both by demands for rights, recognition and participation made by forest peoples and their allies, but also by the necessary forms of social ordering and social relationship for REDD+ to 'work'. From a governance perspective the conditions necessary for REDD+ to work are multiple, and not always easily aligned or alignable: 'successful' implementation therefore requires a 'governmental' rationality that can balance multiple objectives that are sometimes in tension with one another, and at times contradictory. ${ }^{110}$ These include: the necessity of avoiding conflict and maintaining stability in forest spaces, ensuring contractual performance and effective conservation outcomes, producing cost-effective offset, efficiently utilizing local populations as workers on these payment for environmental services schemes, maintaining social legitimacy of the 'carbon commodity' through rights promotion, enabling pricing mechanisms to have 'incentivizing' effects at the 'lowest' and most decentralized level, and avoiding social dislocation and dispossession.

Discussion on the 'social' in REDD+ debates can be seen as describing and managing a complex encounter between the demands of peoples living in and around forest areas and transnational experts seeking to manage their conduct, in which 'neither side pulls in a single direction'. ${ }^{111}$ The 'social' therefore becomes a frame that tries to hold together heterogeneous demands, perspectives and considerations, which at times conflict and at other times converge. There is recognition in the literature that in order for REDD+ projects to be sustainable or lasting over time, to have the social legitimacy upon which the offset commodity depends and to be able to provide investor confidence, security and certainty, the rights of local communities need to be recognized and respected. ${ }^{112}$ There is also increased empirical evidence that community-managed

109. See for example, Ambreena Manji, The Politics of Land Reform in Africa: From Communal Tenure to Free Markets (Zed Books, 2006).

110. See Tania Murray Li, 'Practices of Assembledge and Community Forest Management' (2007) 36(2) Economy and Society 263.

111. Tania Murray Li, 'Indigeneity, Capitalism, and the Management of Dispossession' (2010)

51(3) Current Anthropology 385, 386.

112. Patrick Anderson, 'Free, Prior, and Informed Consent in REDD+: Principles and Approches for Policy and Project Development' (RECOFTC (The Centre for People and Forests) and GIZ, 2011), 17. 
forests produce better conservation outcomes than state protected areas. ${ }^{113}$ In response to such findings, CIFOR argues that 'community-managed forests could be a more cost-efficient and effective solution to reducing deforestation and ensuring the sustainable use of forests while benefiting local livelihoods' ${ }^{114}$ In some discussions rights are described as serving 'efficiency' and 'effectiveness' objectives. In these discourses 'social impacts' are not understood only or even primarily within a rights/obligation model, but also as a factor to be taken into consideration when calculating short- and long-terms project risks. For example, the Eliasch Report stresses that ensuring procedural rights means that REDD+ is 'more likely to succeed and benefit the poor'. ${ }^{115}$ Other authors closely link the need for REDD+ to be propoor with the fact that the mechanism derives 'much of its legitimacy and potential effectiveness from its ability to improve the welfare of the forest-dependent poor and foster development in some of the poorest regions of the world'. ${ }^{116}$ A further argument made in support of 'pro-poor' approaches is that they help consolidate the labour-base upon which PES schemes depend and promote the 'niche-market' returns that co-benefits offer. ${ }^{117}$ A legal manual prepared by Baker \& McKenzie on the CDM discussed community opposition as a 'risk' to projects that might cause costly delays. It suggests such risks can be 'mitigated by ensuring community consents are a condition precedent, and that the community (via community representatives) is consulted in all stages of the process. ${ }^{118}$ The 'social' therefore can be understood as a terrain of struggle that Partha Chatterjee identifies as the "politics of the governed', where 'particular population groups receive attention from these agencies according to calculations of political expediency'. ${ }^{119}$ 'Political expediency' is made up by the complex interplay of short- and long-term economic considerations, the necessity for offset projects to develop public and consumer legitimacy and techniques for managing subaltern resistance.

113. Luciana Porter-Bolland et al., 'Community Managed Forests and Forest Protected Areas: An Assessment of their Conservation Effectiveness Across the Tropics' (2012) 268 Forest Ecology and Management 6.

114. CIFOR, 'Deforestation Much Higher in Protected Areas than Forests Run by Local Communities, 23 August 2011, <http://www.cifor.org/press-releases/deforestation-much-higher-inprotected-areas-than-forests-run-by-local-communities/>.

115. Eliasch, above (n 2), 192 (my emphasis).

116. David Brown, Frances Seymour and Leo Peskett, 'How Do We Achieve REDD Cobenefits and Avoid Doing Harm?', in Arild Angelsen (ed), Moving Ahead With REDD: Issues, Options and Implications (CIFOR, 2008).

117. Leo Peskett et al., 'Making REDD Work for the Poor' (Poverty Environment Partnership, 2008) <https://www.odi.org/sites/odi.org.uk/files/odi-assets/publications-opinion-files/ 3451.pdf $>$. See also 'Consolidation Report: Reducing Emissions from Deforestation and Forest Degradation in Indonesia' (Ministry of Forestry of the Republic of Indonesia, 2008) $<$ http://www.forestcarbonpartnership.org/fcp/sites/forestcarbonpartnership.org/files/Documents/PDF/IFCA_Consolidation_report_REDD_Indonesia.pdf $>$, in which the promotion of co-benefits is advocated for on the basis that they would increase the economic value of the carbon offset commodity; see also Eliasch, above (n 2), 2008, 192 and Cotula and Mayers, above (n 49).

118. 'Legal Issues Guidebook to the Clean Development Mechanism' (Baker \& McKenzie and UNEP, 2004), 90.

119. Partha Chatterjee, The Politics of the Governed: Reflections on Popular Politics in Most of the World (Columbia University Press, 2004), 40. 


\subsection{Processes towards free, prior and informed consent}

Discussions on the need for processes of free, prior and informed consent in REDD+ always reference the principles of international human rights law and the rights of indigenous peoples, however the discussions on FPIC processes in REDD+ also frame such processes as an important risk management strategy. ${ }^{120}$ As such, many of the discussions of FPIC in REDD+ echo similar discussions around 'community consent' as a risk management strategy in corporate social responsibility accounts. ${ }^{121}$ In these discourses the risks of ignoring social and environmental issues are understood as aspects of financing risk, construction risk, operational risk, reputational risk, credit/corporate risk, host government risk and host country political risk, where these risks increase if there is 'social unrest and conflict caused by disagreement or disaffection' by affected communities. ${ }^{122}$ In contrast, being able to demonstrate community support is presented as an 'opportunity' that benefits companies because it makes it 'easier to gain regulatory approval for future projects, efficiently bring their products to market, attract skilled employees, or market their products to the growing pool of customers who consider production conditions and corporate sustainability practices in their purchasing decisions'. ${ }^{123}$ This focus on lack of consent as a risk for project implementers and investors is present even in 'best practice' manuals on FPIC in REDD+. For example, Free, Prior and Informed Consent in REDD+: Principles and Approaches for Policy and Project Development, published by the Centre for Forests and People, presents both deontological and utilitarian arguments for FPIC processes, emphasizing that forest-dependent communities are 'essential to the success of REDD+' and that FPIC processes can assist in successfully implementing pre-determined REDD+ objectives. ${ }^{124}$ The UN-REDD FPIC practice guidelines similarly note that 'inadequate mechanisms for effective participation of local communities in land use decisions could seriously compromise the delivery of both local and global benefits and the long-term sustainability of REDD+ investments'. ${ }^{125}$

\subsection{Proposals for tenure reform}

A similar discourse of pragmatic 'political expediency' is evident in discussions about the need for tenure reform and clarification of tenure rights. The 2009 report Tenure in REDD: Start-point or Afterthought? by the International Institute for

120. See for example, Patrick Anderson, 'Free, Prior, and Informed Consent in REDD+: Principles and Approches for Policy and Project Development' (RECOFTC (The Centre for People and Forests) and GIZ, 2011).

121. See for example, Stephen Herz, Antonio La Vina and Jonathan Sohn, 'Development Without Conflict: The Business Case for Community Consent' (World Resources Initiative, 2007) <http://www.wri.org/publication/development-without-conflict> or Irene Sosa, 'License to Operate: Indigenous Relations and Free, Prior, Informed Consent in the Mining Industry' (Sustainalytics, 2011) <http://www.sustainalytics.com/sites/default/files/indigenouspeople_ fpic_final.pdf $>$.

122. 'The Right to Decide: The Importance of Respecting Free, Prior and Informed Consent' (Amazon Watch Briefing Paper) <http://amazonwatch.org/assets/files/fpic-the-right-to-decide. pdf>.

123. Herz, Vina and Sohn, above (n 121), 6.

124. Anderson, 2011, above (n 112), 47.

125. UN-REDD, 'UN-REDD Programme Operational Guidance: Engagement of Indigenous Peoples \& Other Forest Dependent Communities' (UN-REDD, 23 March 2009), 3. 
Environment and Development (IIED) foregrounded the centrality of tenure and forest governance for both the equity and the effectiveness of REDD+. It is now common for the "creation of equitable legal structures governing the ownership of carbon rights and the ownership of the land in which the trees reside (and the ownership of the trees themselves)' to be described as 'crucial' from both an efficiency and an effectiveness perspective in REDD+ discussions. ${ }^{126}$ The Stern Review stressed that 'defining property rights to forestland ... and determining the rights and responsibilities of landowners, communities and loggers, is key to effective forest management'. ${ }^{127}$ The Eliasch Review emphasized that 'only when property rights are secure, on paper and in practice, do longer-term investments in sustainable management become worthwhile'. ${ }^{128}$ Law firms Convington and Baker \& McKenzie write that 'uncertainty surrounding land title is the single most significant impediment to effective preconditions for a REDD+ scheme ${ }^{129}$ and others have stressed how formalization can ensure 'security of contracts' and 'accurate predictions of returns' in the carbon economy. ${ }^{130}$ The CIFOR publication Realising REDD+: National Strategy and Policy Options states:

tenure must be clarified, not only to create incentives for those managing the forests to properly assign benefits, but also to protect people whose rights could be usurped if REDD+ leads to a rush of command-and-control measures to protect forests, or if REDD+ leads to a resources race when the value of forests increases. ${ }^{131}$

A 2014 report by the World Resource Institute, Securing Rights, Combatting Climate Change, provides 'global-scale' evidence to 'demonstrate the tremendous potential for reducing emissions by strengthening communities' rights' ${ }^{132}$ and presents strengthening community land and resource rights as a 'vital opportunity' to address the urgent crisis of climate change. Tenure reform has also been championed by NGOs such as the Rights and Resources Initiative (launched in 2005) who have been hosting dialogues and conducting research designed to 'foster critical reflection and learning on forest governance, the rights of forest communities and Indigenous Peoples, and forest tenure in the context of global action to combat climate change, including REDD+'. ${ }^{133}$

126. Simon West, "“Command without Control”: Are Market Mechanisms Capable of Delivering Ecological Integrity to REDD?' (2010) 6(3) Law, Environment and Development Journal 298,310 .

127. NH Stern, The Economics of Climate Change: The Stern Review (Cambridge University Press, 2007), 27.

128. Eliasch, above (n 2), 35.

129. Baker \& McKenzie, 'Background Analysis of REDD Regulatory Frameworks' (The Terrestrial Carbon Group and UN-REDD 2009), 40.

130. Cecilia Luttrell, Kate Schreckenberg and Leo Peskett, 'The Implications of Carbon Financing for Pro-poor Community Forestry' (Overseas Development Institute, 2007).

131. William D Sunderlin, Anne M Larson and Peter Cronkleton, 'Forest Tenure Rights and REDD+: From Inertia to Policy Solutions', in Arild Angelsen (ed), Realising REDD+: National Strategy and Policy Options (Center for International Forestry Research (CIFOR), 2009), 141. 132. Caleb Stevens et al., 'Securing Rights, Combating Climate Change' (World Resources Institute and Rights and Resources Iniatitive 2014).

133. IISD, 'RRI Dialogue Bulletin: Summary of the Sixteenth RRI Dialogue on Forests, Governance and Climate Change: Investments, Communities and Climate Change' (Lima, Peru, 2 October 2014) Vol 173, No 8. 


\section{DISCIPLINARY INCLUSION IN THE 'GREEN ECONOMY'}

The previous section demonstrated how in debates over REDD+ implementation there has been an increasing convergence between calls for rights and recognition 'from below' and the imperatives of enforceability of obligations from 'above'. Although REDD+ is an international project, it is constituted and takes shape through national and sub-national institutions. In many ways it is action at the local level that is ultimately determinative of its success or failure. REDD+ is, as Anu Lounela writes, 'a globally produced but place-based project'. ${ }^{134}$ Ultimately, it is activities 'on the ground' that determine whether 'additional' sequestration or carbon 'savings' claimed in credits have a material basis. REDD+ implementation has therefore been required to operate on what I describe as a 'terrain of compromise'. This is due both to the specific nature of the remote, often difficult to access, forest spaces where REDD+ is implemented, as well as to the specific nature of the project. Tanya Murray Li has argued 'the forest edge is a site of struggle, but [one which] is difficult to control by coercive means': ${ }^{135}$

Forest guards are hugely outnumbered by forest users and the terrain, often remote and mountainous, makes surveillance difficult. Laws that exclude people from forests are enforced sporadically and sometimes violently, but it has proven impossible for forest bureaucracies to enforce these laws in a consistent manner. Evictions are routinely followed by re-occupations or new encroachments. ${ }^{136}$

Secondly, forest carbon offsets as a property right depend upon social legitimation. Accounts of conflict or violent evictions risk upsetting the 'social licence' upon which these schemes, in part, depend. Moreover, REDD+ projects need to remain viable for an ongoing period in order to demonstrate permanence. This context presents quite different dynamics from those present in mining or plantation projects that involve a destruction and transformation of the landscape. In REDD+ the need to ensure permanence of projects, as well as the maintenance of social legitimacy over time, suggest inherent limits to controlling peoples in and around these areas, through direct coercive force, to ensure they comply with project prescriptions. Therefore, I suggest REDD+ implementation also utilizes more subtle forms of disciplinary power, policies of conditional inclusion and the enactment of responsible ecological subjectivities. This discussion suggests that there is a different and more complex logic operating in REDD+ implementation than an exclusive focus on the risks of displacement or expulsion suggests. REDD+ is being implemented at a time when the expansionist tendencies of contemporary capitalism mean that indigenous peoples risk wholesale displacement on account of deforestation, plantations, extractive industry projects, dams and other forms of 'land grabs'. ${ }^{137}$ Understandably, the focus of much advocacy has been on avoiding similar outcomes in REDD+ schemes, if governments agree to REDD+ projects on forest land without first consulting the people who live on that land and claim ownership or other rights to it. However, new forms of authority

134. Anu Lounela, 'Climate Change Disputes and Justice in Central Kalimantan, Indonesia' (2015) 56(1) Asia Pacfiic Viewpoint 62.

135. Li, 2007, above (n 110).

136. Ibid, 266.

137. Li, 2010, above (n 111); see also Saskia Sassen, Expulsions: Brutality and Complexity in the Global Economy (Harvard University Press, 2014) and Saskia Sassen, 'A Savage Sorting of Winners and Losers: Contemporary Versions of Primitive Accumulation' (2010) 7(1) Globalisations 23 . 
can be articulated without directly excluding people, but also by reorganizing social relations and relations to land. As James Fairhead, Melissa Leach and Ian Scoones note in their discussion of 'green grabbing', material appropriation can take many forms, including through the restructuring of property and other legal rules by which 'land or resources are removed from the control of their prior users, or access and use rights are limited'. 138

The analysis in this article suggests that the logic underpinning the social in 'bestpractice' REDD+ is not primarily orientated to excluding people, but rather directed to transforming relations between forest peoples and their land, and transforming people who are predominately smallholder agriculturist into entrepreneurial payment for environmental service (PES) workers. That is, strategies to manage the social impact of REDD+ can be read in part as seeking to transform communities from existing as (in the words of the Rights and Resources Initiative) 'unrecognized counter-parties'139 to become legally recognized 'partners' covered by 'village agreements' or by other contractual arrangements, as well as to transform individuals into participants in the green economy and REDD+ project workers. ${ }^{140}$ This analysis builds on anthropologist Tania Murray Li's discussion of REDD+ as forms of '[i]nterventions to fix indigenous peoples to the land, and limit them to specific land uses, [which are] currently being intensified'. ${ }^{141} \mathrm{Li}$ argues REDD+ operates as a form of protection that has the effect of 'fixing [people], once again, in their distinct identities and their arboreal niche' ${ }^{142}$ As such, she characterizes REDD+ as a mode of governing through difference, in which people are 'fixed in place on ancestral/customary land' and 'fixed in their alterity', ${ }^{143}$ in what she describes as the 'communal fix ${ }^{144}$ or the 'tribal slot'. ${ }^{145}$ In these practices one sees echoes of forms of colonial governmentality in which 'rather than [being] eradicated or aggressively modernized, native social and political forms would now be patronized as they became inserted into the institutional dynamics of imperial power'. ${ }^{146}$ However, rather than simply replicating these forms of colonial governance that operate through difference, REDD+ is involved in a more complex promotion of 'tradition' alongside its mobilization for inclusion in neoliberal payments for environmental service markets.

Reconceptualizing the operation and effects of REDD+ in this way requires further critical questions to be asked about the 'instrument effects' ${ }^{147}$ - effects that exceed

138. Fairhead, Leach and Scoones, above (n 23), 247.

139. Alforte et al., above (n 22).

140. For a discussion of the process of finalizing 'village agreements' for the KFCP see Mari Mulyani and Paul Jepson, 'Social Learning through a REDD+ "Village Agreement": Insights from the KFCP in Indonesia' (2015) 56(1) Asia Pacfiic Viewpoint 79 and Howell (n 148).

141. Tania Murray Li, 'Fixing Non-market Subjects: Governing Land and Population in the Global South' (2014) 18 Foucault Studies 34.

142. Ibid, 46.

143. Ibid, 38. See also Li, 2010, above (n 111).

144. $\mathrm{Li}, 2010$, above (n 111), 386-88.

145. Tania Murray Li, 'Articulating Indigneous Identity in Indonesia: Resource Politics and the Tribal Slot' (2000) 42(1) Comparative Studies in Society and History 149; see also Li, 2014, above (n 141), 39.

146. Karuna Mantena, Alibis of Empire: Henry Maine and the Ends of Liberal Imperialism (Princeton University Press, 2010), 2.

147. Michel Foucault, Discipline and Punish: The Birth of the Prison (Knopf Doubleday Publishing Group, 1977) cited in Balakrishnan Rajagopal, International Law from Below: Development, Social Movements and Third World Resistance (Cambridge University Press, 2003), 76. 
intended or desired effects - of the measures discussed, such as tenure reform and consultation towards FPIC. I suggest that these proposed measures to mitigate the risks and promote the benefits of REDD+ themselves have productive effects and may work to further consolidate the reorganization of authority that REDD+ represents. This reading suggests that these safeguard strategies do not simply mitigate the potential negative harms or risk of dispossession that REDD+ presents, but can also operate to integrate peoples living around forest areas into the 'green economy': to fix them in place as workers on and/or beneficiaries of payment for environmental services schemes, while their forests and land, newly commoditized as 'natural capital', enters into international financial flows. In this way, these strategies may also operate to more deeply embed market rationalities by facilitating the responsibilization of the contracting subject upon which REDD+ depends.

In foregrounding the processes of disciplinary inclusion operative in REDD+ schemes, this analysis does not seek to contest or dispute the reality and ongoing risk of coercive and dispossessory violence against forest communities through REDD+ schemes. There remain, as activists and scholars have shown, persistent gaps between policy and practice in REDD+ implementation. ${ }^{148}$ Further, research by the Rights and Resources Initiative has found that although most countries with REDD+ strategies and all leading international REDD+ initiatives have committed to recognizing tenure rights, there has actually been a significant slowdown in the recognition of rights on the ground between 2008 and 2013 compared to the period 2002-2008. ${ }^{149}$ Moreover, it is foreseeable that as livelihoods are transformed and forest communities become increasingly reliant upon highly fluctuating and unstable international carbon prices for income, impersonal pressures from competitive global markets may generate slower and more attritional processes of displacement. ${ }^{150}$ Legal rights to financial benefits from REDD+ do not in themselves ensure that these financial benefits are sufficient to compensate for the forms of livelihood REDD+ could displace.

In the following sections I discuss how both tenure reform and the processes leading to the articulation of consent operate as sites of struggle, deployed both to support claims for greater rights and authority for local communities but also to consolidate the formalization of neoliberal market obligations and responsibilities. César Rodríguez-Garavito has argued that processes of consultation towards free, prior and informed consent mark a point of convergence where two different legalities meet: where 'neoliberal legality based on freedom of contract and due process' is contested by a 'legality that is based on indigenous self-determination'. ${ }^{151}$ Similarly, there is a definite ambiguity in the

148. Signe Howell, "No RIGHTS - No REDD”: Some Implications of a Turn Towards CoBenefits' (2014) 41(2) Forum for Development Studies 253; Kill, above (n 65); see also Paul Kanyinke Sena, Myrna Cunningham and Bertie Xavier, Indigenous People's Rights and Safeguards in Projects Related to Reducing Emissions from Deforestation and Forest Degradation: Note by the Secretariat, UN ESCOR, Permanent Forum on Indigenous Issues, 12th sess, Agenda Item 5, UN Doc E/C.19/2013/7 (5 February 2013) para 26.

149. 'Status of Forest Carbon Rights and Implications for Communities, the Carbon Trade and REDD+ Investments' (Rights and Resources Initiative, March 2014), 1-2.

150. For a discussion of the need to pay attention to more 'piecemeal', 'unexpected' and 'unplanned' agrarian changes and not just the 'spectacular episodes of dispossession by corporations (land grabbing)', see Tania Murray Li, Land's End: Capitalist Relations on an Indigenous Frontier (Duke University Press, 2014), 9.

151. César Rodríguez-Garavito, 'Ethnicity.gov: Global Governance, Indigenous Peoples, and the Right to Prior Consultation in Social Minefields' (2011) 18(1) Indiana Journal of Global Legal Studies 263, 282. 
term 'tenure reform': traditionally it referred to a redistributive practice of granting land to landless workers ${ }^{152}$ but in recent decades it has come to refer to neoliberal models of 'negotiated' or 'market-assisted' land reform directed towards clarifying obligations and transforming land into a marketized commodity. ${ }^{153}$ Critical commentators have therefore argued that neoliberal land formalization projects are not only concerned with the codification of existing social relations but also with the production of marketized social relations and the subjectivity of homo oeconomicus. ${ }^{154}$ Hermando de Soto in The Mystery of Capital stressed that the power of property comes from the way it 'transforms people with property interests into accountable individuals', thereby 'creating individuals from masses'. ${ }^{155}$ Formalization is for him a disciplinary process and he celebrates how property's power manifests itself in the 'accountability it creates, from the constraints it imposes, the rules it spawns and the sanctions it can apply'. ${ }^{156}$

In the discussion below I highlight these tensions in how these processes can support both claims for rights 'from below' but also imperatives of responsibilization 'from above'. I examine the discourses surrounding and operation of both these safeguards in the context of REDD+ implementation. I suggest that in this context some of the more radical potentials of these safeguards have been neutralized in specific ways and that therefore they may not operate as those calling for them would hope or envision, unless broader dynamics are addressed.

\section{TENURE REFORM AS A STRATEGY FOR 'FIXING PEOPLE IN PLACE'}

In this section I explore the way that tenure reform can operate as a strategy for 'fixing people in place' while also enabling the inclusion of customary land in international markets. In doing so, I pay attention to both the content of the rights that tenure reform grants, and the way in which tenure rights to land has in the carbon economy become nested in a layered system of property rights, where the rights associated with title have been 'hollowed' out, and become devoid of the key attributes of property, namely management and control rights. Generally, forest tenure reform programmes (in contrast to agrarian reforms) have often granted rights (normally collective rights) but retained principal rights such as alienation with the state on the premise that forests are a 'public good'. ${ }^{157}$ Forest tenure rights therefore are not akin to other property rights in that they do not allow forest land to become a commodity circulating in land markets. Describing forest tenure reform as an 'orphan with only uncles', ${ }^{158}$ Barry,

152. MR El-Ghoney, 'Land Reform Development Challenges of 1963-2003 Continue into Twenty-First Century' FAO, <http://www.fao.org/docrep/006/j0415t/j0415t05.htm>.

153. Deborah Barry, Anne M Larson and Carol J Pierce Colfer, 'Forest Tenure Reform: An Orphan with Only Uncles', in Anne M Larson et al. (eds), Forests for People: Community Rights and Forest Tenure Reform (Earthscan, 2010) 23.

154. David Williams, 'Constructing the Economic Space: The World Bank and the Making of Homo Oeconomicus' (1999) 28(1) Millennium - Journal of International Studies 79.

155. Hernando de Soto, The Mystery of Capital: Why Capitalism Triumphs in the West and Fails Everywhere Else (Black Swan, 2000), 53.

156. Ibid, 54-5.

157. Barry, Larson and Colfer, above (n 153), 22; see also Arun Agrawal and Elinor Ostrom, 'Collective Action, Property Rights, and Decentralisation in Resource Use in India and Nepal' (2001) 29(4) Politics and Society 485 who argue that community forest proposals in Nepal and India only devolved 'operational-level' rights.

158. Barry, Larson and Colfer, above (n 153), title and 39. 
Larson and Colfer trace three conflictual influences of forest tenure reform. These are: indigenous peoples' demands for recognition and rights; global biodiversity conservation imperatives; and decentralization programmes, often imposed as part of structural adjustment programmes. ${ }^{159}$

In the next subsection, I outline these different influences, namely decentralization, the promotion of 'common property regimes' and their formalization in the context of biodiversity policy and community forest management. As such, I situate the push for tenure reform in REDD+ within a broader context of governance strategies in which the 'local' is deployed in the interests of the 'global', or in which processes of localization are promoted to serve 'global' objectives. The promise of such governance strategies is that there will be a productive alignment of 'local' and 'global' interests that produces the elusive 'win-win-win' scenario that is heavily invoked but rarely realized in REDD+. However, the 'dark side' of such governance strategies is that the granting of local rights can become conditional upon, or realizable only to the extent that they facilitate the agenda of market-based conservation; that is, to the extent that they can support the promotion of a rights discourse which supports only those rights that are exercised responsibly towards predetermined ends in pursuit of a posited global 'common concern'. In this way, there is a danger that such discourses of rights do not provide an adequate vocabulary to advocate for or to enable alternative, autonomously determined futures.

\subsection{Decentralization}

In the last two decades development discourses have focused on the practice of processes of decentralization. ${ }^{160}$ Decentralization has been promoted in many contexts, including for the 'improvement' of forest governance. ${ }^{161}$ Such prescription and policies, as Luis Eslava has identified, are part of an 'international trend that perceives the state as an oversized, unsustainable and unevenly developed jurisdiction', and are directed to the reconfiguration of the state through localization rather than its dissolution. ${ }^{162}$ Decentralization is presented not as in opposition to, or an alternative to, centralization, but as a complementary mode of governing that should be utilized when it presents the 'most effective ways and means of achieving a desired objective'. ${ }^{163}$ Wendy Brown identifies the devolution of authority as a key feature of neoliberal

159. Barry, Larson and Colfer, 2010, above (n 153).

160. See Richard Flaman, 'Decentralisation: A Sampling of Definitions' (UNDP Working Paper, 1999).

161. See Moira Moeliono, Eva Wollenberg and Godwin Limberg (eds), The Decentralization of Forest Governance: Politics, Economics and the Fight for Control of Forests in Indonesian Borneo (Earthscan 2009); Christopher Barr et al. (eds), Decentralization of Forest Administration in Indonesia: Implications for Forest Sustainability, Economic Development and Community Livelihoods (Center for International Forestry Research (CIFOR), 2006). For a discussion of the failures of decentralization in relation to forests see: Luke Arnold, 'Deforestation in Decentralised Indonesia: What's Law Got to Do With It?' (2008) 4(2) Law, Environment and Development Journal 75.

162. Luis Eslava, 'Decentralization of Development and Nation-Building Today: Reconstructing Colombia from the Margins of Bogotá' (2009) 2(1) The Law and Development Review 282, 283.

163. UNDP, 'Factors to Consider in Designing Decentralized Governance Policies and Programmes to Achieve Sustainable People-Centered Development' (Management Development and Governance Division, February 1998) cited in Flaman, above (n 160), 3. 
governance, driven by both a 'formal antipathy to centralized state power' and by an 'emphasis on problem solving achieved by stakeholders'. ${ }^{164}$ She clearly and carefully distinguishes the neoliberal devolution of power and responsibility from 'thoroughgoing decentralization and local empowerment', noting that neoliberal devolution frequently delegates responsibility on the principle of subsidiarity to 'small and weak units [that are] unable to cope ... technically, politically, or financially'. ${ }^{165} \mathrm{In}$ Brown's account, a key effect of devolution is not effectiveness, but rather the 'seeding' of competition between administrative units 'aimed at "entrepreneurialising" them'. ${ }^{166}$ She argues that the devolution of authority is therefore strategically related to responsibilization as a social policy, in which the 'entity at the end of the pipeline' is tasked with cultivating themselves as a 'wholly accountable actor' ${ }^{167}$ In contrast to 'responsibility', which as an act speaks of the human capacity for autonomy, Brown argues that its linguistic conversion to responsibilized describes an 'administered condition' that 'departs from the domain of agency' and where the subject is governed through an 'external moral injunction'. The 'process-based transitive verb' responsibilization, she argues, represents a further transformation and signals a 'regime in which the singular human capacity for responsibility is deployed to constitute and govern subjects and through which their conduct is organized and measured, remaking and reorientating them for a neoliberal order'. ${ }^{168}$ The neoliberal strategic relation between devolution and responsibilization therefore creates an order of decentralized governance, but one in which self-disciplined subjects orientate themselves towards an already determined globalist rationality. This represents not a dismantling of global authority but a reconfiguration of its forms of exercise and implementation, in which the 'local' can be strategically deployed as the level through which internationalized visions of development come into being.

\subsection{Land formalization, commons and customary recognition}

Over the past few decades World Bank land formalization projects have overwhelmingly pursued a highly controversial policy of dismantling communal land ownership structures and replacing them with regimes of secure privatized property. ${ }^{169}$ However, from the mid-1990s onwards World Bank land formalization programmes have increasingly recognized the strategic value of communally owned land in some circumstances, and especially for natural resource management. A 1989 World Bank Discussion Paper by Daniel Bromley and Michael Cernea, The Management of Common Property Natural Resources, distinguished 'common property regimes' (CPRs) from 'open access regimes'. The authors clarified that CPRs were not a 'free-for-all' but rather a 'structured ownership arrangement in which management rules are developed, group size is known and enforced, incentives exist for co-owners to follow the accepted institutional arrangements, and sanctions work to ensure

164. Wendy Brown, Undoing the Demos: Neoliberalism's Stealth Revolution (Zone Books, 2015), 131-4.

165. Ibid, 132.

166. Ibid.

167. Ibid, 133.

168. Ibid, 133.

169. For an overview and critique of these programmes, and their gendered effects see Manji, above (n 109). 
compliance'. ${ }^{170}$ The authors then attribute resource degradation not to a 'tragedy of the commons ${ }^{171}$ but to 'the dissolution of local-level institutional arrangement whose very purpose was to give rise to resource use patterns that were sustainable'. ${ }^{172}$ They warn that there is no empirical support for the notion that national (or regional) governments can 'effectively' manage natural resources and warn that 'natural resource projects in the developing world that do not actively incorporate the local users will ultimately fail'. ${ }^{173}$ The production of expert knowledge on the commons became a key World Bank objective, and in 1995 the Common Property Resources Management Network (CPRNet) was established to connect World Bank staff with external practitioners and experts. ${ }^{174}$ The establishment of this research group was based on a recognition that:

In comparison with privately owned and managed, as well as state-controlled resources, CPRs play a crucial role in: (i) Reducing rural poverty and inequality; (ii) Maintaining local-level biodiversity and micro-level environmental stability; (iii) Enhancing agricultural productivity and diversity; and, (iv) Promoting collective sharing and group action. ${ }^{175}$

CPRNet's aims included 'enhancing awareness' about CPRs as 'institutional modalities' and 'resources that are managed collectively' within the World Bank. It also sought to increase understanding of the 'dynamic interplay of various types of property rights' regimes on the local level' and the importance of common property regimes for the 'correct targeting of World Bank Group investment operations'. In 1998 an International Workshop on Community Based Natural Resource Management was held in Washington DC, ${ }^{176}$ together with key strategic partner the International Association for the Study of the Commons (IASC), founded and directed by Elinor Ostrom. Subsequently, a voluminous body of literature has been produced on CPRs, with the Vincent and Elinor Ostrom Workshop in Political Theory and Policy Analysis as a central node for the development of theoretical frameworks for and ethnographic investigations of CPRs. ${ }^{177}$ George Caffentzis notes how this interest has 'transformed common property from being a relic to a live option in the World Bank's strategic "development" literature'. ${ }^{178}$ Michael Goldman demonstrates how the

170. Daniel W Bromley and Michael M Cernea, 'The Management of Common Property Natural Resources' (The World Bank 1989).

171. Garrett Hardin, 'The Tragedy of the Commons' (1968) 162(3859) Science 1243.

172. Bromley and Cernea, above (n 170).

173. Ibid.

174. George Caffentzis, 'The Future of "The Commons": Neoliberalism's "Plan B" or the Original Disaccumulation of Capital?' (2010) 69 New Formations 23, 40.

175. The World Bank Group's Common Property Resource Management Network: Guide to CPRNet $<$ http://info.worldbank.org/etools/docs/library/97605/conatrem/conatrem/documents/ guide-3b.pdf $>$.

176. Ibid; see also The International Workshop on Community-based Natural Resource Governance (CBNRG), Washington DC, 10-14 May 1998, 'Workshop Report' <http://info.worldbank. org/etools/docs/library/97605/conatrem/conatrem/documents/May98Workshop_Report.pdf>.

177. See for example, Paul Dragos Aligica, Institutional Diversity and Political Economy: The Ostroms and Beyond (Oxford University Press, 2014); Paul Dragos Aligica and Peter J Boettke, Challenging Institutional Analysis and Development: The Bloomington School (Routledge, 2009) and Michael D McGinnis (ed), Polycentric Governance and Development: Readings from the Workshop in Political Theory and Policy Analysis (University of Michigan Press, 1999).

178. Caffentzis, above (n 174), 33. 
adoption of 'commons discourse' by an epistemic community concerned with questions of global resource management reconfigured understandings of commons, so that the 'problem' of commons and their management becomes 'global' rather than 'local'. ${ }^{179}$ The stakes of formalization in these accounts is not primarily the replacement of diverse ontologies of property with that of the individualized private rights characteristic of Western modernity. Instead the land formalization literature promotes hybrid systems, directed towards finding a 'middle way' between customary land tenure and modern, Western legal systems. ${ }^{180}$ These hybrid models of formalization facilitate the strategic recognition of 'customary property regimes' so that 'commons qua firm'" 181 can be incorporated into global capitalist strategies or accumulation. These hybrid formalization models allow for, and even encourage, 'local' mechanisms of internal dispute resolution for 'internal' disputes, even as they facilitate 'external' disputes between collectives and external investors being regulated by formal state law. ${ }^{182}$ What emerges is a complex framework of legal pluralism, that recognizes and deploys customary law for 'internal' disputes, but externally the commons become subject to state law as the ultimate container of social relations. In this way, both the models of decentralization described and processes of formalization promote conditional localized self-governance, but in doing so operate to ensure that local self-governance is exercised in specific ways that are facilitative of 'global' interests.

\subsection{Tenure reform through project implementation}

Another key way in which the more radical possibilities inherent in calls for tenure reform have been neutralized is when tenure reform is presented as a positive outcome of a REDD+ project, rather than a precondition for a REDD+ project. In REDD+ literatures the process of tenure clarification and formalization is staged as operating within a circular logic; that is, these processes are presented as both a necessary precondition for REDD+ implementation, while REDD+ implementation is also simultaneously presented as incentivizing such reforms. ${ }^{183}$ This envisioned circularity in which REDD+ is presented as both the cause and product of tenure reform allows implementing agencies to map two different trajectories for formalization. In one, formalization of rights is part of a project implementation, but a process that occurs after the decision is made to locate a REDD+ project on a specific site. Against this, a key claim of indigenous peoples has been to insist on 'rights before REDD+' or 'no rights, no REDD+'. Such claims stress that the authority to decide about REDD+ projects needs to lie with affected peoples and that consultation towards free, prior and informed consent is critical.

The Kalimantan Forest Carbon Partnership (KFCP) is a 'demonstration project' that is part of Australia's \$200 million International Forest Carbon Initiative (IFCI), which

179. Michael Goldman, "Customs in Common": The Epistemic World of the Commons Scholars' (1997) 26(1) Theory and Society 1, 15.

180. See 'Making Land Work: Reconciling Customary Land and Development in the Pacific' (AusAID, Commonwealth of Australia, 2008).

181. Caffentzis, above (n 174), 2010.

182. 'Making Land Work' above (n 180).

183. Annalisa Savaresi and Elisa Morgera, 'Ownership of Land, Forest and Carbon', in John Costenbader (ed), Legal Frameworks for REDD: Design and Implementation at the National Level (IUCN Environmental Policy and Law Paper No. 77, 2009) 15, 18. 
sought to rehabilitate 120,000 hectares of land degraded by the disastrous Soeharto-ero Ex-Mega Rice Project in Central Kalimantan. First announced in September 2007, it was quietly ended in July $2013^{184}$ (although certain targeted areas of work continued until June 2014) despite few of its initial targets having been achieved. It serves as a useful illustration of this model of implementation in which the decision to launch the project and its location was made at the inter-governmental level without consultation with the affected peoples. Their 'consent' and engagement in the project was sought subsequently in a fraught and complex 'socialization' process. ${ }^{185}$ The KFCP however argues that tenure rights will be enabled through or by the project; tenure rights in this sense are subsequent to the assumption of contractual obligations. In the language of the KFCP design documents, the rights of community members can be promoted 'through' the project, as a result of the project implementation. However, the document explicitly rejects clarification and recognition of land tenure as a precondition for the KFCP and argues instead that the project itself may facilitate tenure reforms:

Clear land tenure laws cannot be made a precondition of project development, because no projects would then ever be developed or they would all be developed in the same handful of places. Rather, the projects themselves can be made the instrument of change, where community management rights are first given to local people in a step-wise process to full land tenure. ${ }^{186}$

If tenure rights are granted through formalization after contractual decisions about how that land can be used have already been decided, the tenure rights granted are 'hollow' and lack salient attributes of property as such title is already divested from the right to control land and decide future land-use activities. Such tenure reform through REDD+ projects therefore cannot be equated to rights asserted by forest peoples to 'own, control, use and peacefully enjoy their lands, territories and other resources, and be secure in their means of subsistence' ${ }^{187}$

\section{7 'RIGHTS BEFORE REDD+': TENSION IN REDD+ CONSENT PROCESSES}

Against the promises of rights recognition and tenure reforms through REDD+ projects, many of the peoples affected by REDD+ projects have called for 'rights before REDD+' and for the principle of free, prior and informed consent (FPIC) to be applied to all projects. In this section, I discuss the process of FPIC in REDD+ to again identify how the radical potential of this demand is being neutralized in its implementation.

The right of consultation towards FPIC is articulated in several rights documents, including the UNDRIP and ILO Covenant 169, in human rights jurisprudence and

184. For a critical appraisal see Rebecca Pearse, 'Don't Cry for Carbon in Kalimantan', New Matilda, 2 July 2013 <http://newmatilda.com/2013/07/04/dont-cry-carbon-kalimantan> and Stephen Howes, 'KFCP: Begun with a Bang, Ending with a Whimper', DevPolicyBlog, 1 July $2013<$ http://devpolicy.org/in-brief/kfcp-begun-with-a-bang-ending-with-a-whimper20130701-2/>.

185. See Mulyani and Jepson, 2015, above (n 140) and Lounela, 2015, above (n 134).

186. 'Australia Indonesia Partnership', 'Kalimantan Forests and Climate Partnership (KFCP): Design Document' (2009), 19 fn 11; see also Pearse and Dehm, above (n 12), 16.

187. See Marcus Colchester, 'Beyond Tenure: Rights-based Approaches to Peoples and Forests. Some Lessons from the Forest Peoples Programme' (Paper presented at the International Conference on Poverty Reduction in Forests: Tenure, Markets and Policy Reforms, Bangkok, Thailand, 3-7 September 2007 2007), 4. 
even in the consultation draft of the proposed new World Bank indigenous peoples safeguard. ${ }^{188}$ Several 'best practice' guidelines on FPIC in REDD+ have been prepared, including Free, Prior and Informed Consent in REDD+: Principles and Approaches for Policy and Project Development (February 2011), authored by Patrick Anderson and released by RECOFT, The Centre for Peoples and Forests ${ }^{189}$ and the UN-REDD Programme Guidelines on Free, Prior and Informed Consent (January 2013). These draw on international human rights norms and guidance documents ${ }^{190}$ and stress that "consent must be freely given, obtained prior to implementation of activities and be founded upon an understanding of the full range of issues implicated by the activity or decision in question', ${ }^{191}$ and that the right to consent includes also the right to withhold consent.

Despite these policy documents, several studies from the field have documented clear problems in the implementation of FPIC processes in REDD+. These include reports about failure to live up to the standards outlined in policy documents, the use of inappropriate and inaccessible language in consultation processes and a 'general pattern of uncertainty, unpreparedness and lack of planning'. ${ }^{192}$ There is a growing body of scholarship that demonstrates both the existence of a 'gap' between REDD+ policy documents and actual practice on the ground, and which seeks to 'ascertain reasons for, and effects of, this gap'. ${ }^{193}$ Other studies have found that the many still unanswered questions about REDD+'s financing and the long-term trajectories of carbon markets make it almost impossible to provide sufficient precise information on the basis of which a community could make an informed decision about a proposal. ${ }^{194}$

The analysis in this section is, however, orientated to exploring the various aspects of the discourse field and the legal principles surrounding FPIC that limit in various ways the ability of communities to 'veto' REDD+ projects. Tania Murray Li in her discussion of REDD+ writes that:

It is not clear that forest villagers, whose participation is essential for a consensus version of REDD+, actually have the option to make the wrong' choice - to cut forests, to reject REDD+ programs and REDD+ funds in favour of different goals or different productive arrangements. ${ }^{195}$

Li's suggestion that a community's refusal of consent is read as a 'wrong' decision and that people making such decisions are perceived as uninformed, unauthentic or biased by project implementers is substantiated by other field accounts. In an interview I conducted, UN-REDD staff members in Indonesia who were then in the

188. World Bank, ESS7 (consultation draft), para 19.

189. Anderson, 2011, above (n 112).

190. Including the Report of the International Workshop on Methodologies Regarding Free, Prior and Informed Consent and Indigenous Peoples (New York, 17-19 January 2005), UN Permanent Forum on Indigenous Issues, Fourth Session, E/C.19/2005/3 (17 February 2006) and Final Study on Indigenous Peoples and the Right to Participate in Decision-Making: Report of the Expert Mechanism on the Right of Indigenous Peoples, Human Rights Council, Expert Mechanism on the Rights of Indigenous Peoples, 4th session, A/HRC/EMRIP/2011/2 (26 May 2011).

191. UN-REDD Programme, UN-REDD Programme Guidelines on Free, Prior and Informed Consent (January 2013), 7.

192. Howell, above (n 148), 265-6.

193. Ibid, 254.

194. See ibid, 255-6.

195. Li, 2014, above (n 141), 46. 
process of developing a 'best practice' FPIC process, responded to a question about a community withdrawing consent for a REDD+ project by expressing bewilderment. ${ }^{196}$ Such a community response to them did not make sense, as REDD+ projects were not 'bad' or 'harmful' but in the community's best interest. They characterized the withdrawal of consent as an informational problem: a community would withdraw consent, not because they didn't want REDD+ but because the information was not fully available for them to understand the implications for the future. ${ }^{197}$ As such, withdrawal of consent would require project staff to visit a few times to give them more information. ${ }^{198}$ In her discussion of a REDD+ pilot project in Sulawesi, Howell documented how the Indonesian Ministry of Forestry attributed a community vote against the UN-REDD pilot project to 'inappropriate interference' by local NGOs. ${ }^{199}$ In her study of the KFCP in Central Kalimantan, Lounela has described how Ngaju Dayaks villagers organizing against the project, who had connections with advocacy NGOs such as WAHLI, 'were considered egotistic by the village elite, of whom many gained economic benefits from the REDD+ project'. ${ }^{200}$ The examples show how opposition to REDD+ is understood as 'uninformed' or interpreted as not being a rational and informed decision, but the product of undue influence by ideological outsiders, or (paradoxically) alternatively as being the effect of undue self-interest. These examples suggest that paternalistic attitudes, stereotypes and vested interests very much impinge upon the facilitation of local consent processes.

In the next section I discuss how some of the assumptions that lead refusal of consent in the REDD+ to be viewed as a 'wrong' decision are in some ways replicated within international human rights laws. I suggest that the legal frameworks for indigenous rights and processes towards consent are such that it becomes very difficult for forest peoples to be legible as 'Indigenous', 'informed' and 'not consenting' simultaneously. In the subsections below I explore aspects of international law relating to processes of FPIC: (1) the reorientation of international law relating to indigenous peoples away from self-determination and decolonization in an indigenous sovereignty framework and towards the protection of culture in a human rights framework; (2) legal debates on the definition of indigeneity; (3) the increasing points of convergence between international law relating to indigenous peoples and the environment; and (4) recent interpretations by the former Special Rapporteur James Anaya of the obligation of consultation towards FPIC. Finally, I discuss some of the potential disciplinary 'instrument effects' of FPIC processes.

\subsection{International law and indigenous peoples}

Since the late 1980s the positions advanced by indigenous peoples in international forums has arguably shifted from 'self-determination' or 'sovereignty' arguments towards a human rights model focused on 'cultural identity' and 'internal rather than external self-determination'. ${ }^{201}$ This latter approach has been promoted by key

196. Interview with UN-programme, Indonesia, February 2011, copy on file.

197. Ibid.

198. Ibid.

199. Howell, above (n 148), 263.

200. Lounela, above (n 140), 74.

201. See in particular Karen Engle, 'Indigneous Rights Claims in International Law: Selfdetermination, Culture, and Development', in David Armstrong (ed), Routledge Handbook 
advocates such as James Anaya as a more pragmatic and 'realistic' route to indigenous rights. ${ }^{202}$ Critical scholars have highlighted the limitations of human rights models and culturist arguments. Isabelle Schulte-Tenckhoff identifies a 'growing tendency to collapse indigenous peoples and minorities' and to limit collective rights to 'human rights exercised by individuals in community with other members of their group, as opposed to group rights claimed by non-state groups as such'. ${ }^{203}$ She warns that 'recognition of cultural rights comes at the price of the right of self-determination understood as a group right'. ${ }^{204}$ Also, Karen Engle has argued that the 'dark side' of such 'strategic essentialism' 205 and the focus on human rights of cultural identity rather than on a broader claim of self-determination is that, even when articulated in group terms, such rights 'function to protect the group, rather than transform the underlying power structures against which they are protecting the group' and therefore might be 'short-sighted and even counter productive'. ${ }^{206}$ This reorientation has shifted the tools international law provides for indigenous peoples to claim authority over their land and to freely decide their collective destinies. In the REDD+ context therefore, I suggest that international law has provided tools for indigenous people more adapted to realizing rights within a framework of rearticulated authority over forested areas, than to contesting the reorganization of authority over forest areas itself.

of International Law (Routledge, 2009) 331; Karen Engle, The Elusive Promise of Indigenous Development: Rights, Culture, Strategy (Duke University Press, 2010); Karen Engle, 'On Fragile Architecture: The UN Declaration on the Rights of Indigenous Peoples in the Context of Human Rights' (2011) 22(2) The European Journal of International Law 141; Isabelle Schulte-Tenckhoff and Adil Hasan Khan, 'The Permanent Quest for a Mandate: Assessing the UN Permanent Forum on Indigenous Issues' (2011) 20(3) Griffith Law Review 673; Isabelle Schulte-Tenckhoff, 'Treaties, Peoplehood, and Self-determination: Understanding the Language of Indigenous Rights' in Elvira Pulitano (ed), Indigenous Rights in the Age of the Declaration (Cambridge University Press, 2012) 64; and Irene Watson and Sharon Venne, 'Talking Up Indigenous Peoples' Original Intent in a Space Dominated by State Interventions' in Elvira Pulitano (ed), Indigenous Rights in the Age of the Declaration (Cambridge University Press, 2012) 87.

202. S James Anaya, 'Divergent Discourses About International Law, Indigenous Peoples, and Rights over Land and Natural Resources: Towards a Realist Trend' (2005) 16(2) Colorado Journal of International Environmental Law and Policy 237. See also S James Anaya, 'Indigneous Rights Norms in Contemporary International Law' (1991) 8 Arizona Journal of International and Comparative Law 1; S James Anaya, 'The Capacity of International Law to Advance Ethnic or Nationality Rights Claims' (1991) 13(3) Human Rights Quarterly 403; James Anaya, 'Indigenous Peoples' Participatory Rights in Relation to Decisions about Natural Resource Extraction: The More Fundemental Issue of what Rights Indigneous Peoples Have in Land and Resources' (2005) 22(1) Arizona Journal of International and Comparative Law 7.

203. Schulte-Tenckhoff, 2012 (n 201), 64.

204. Ibid, 67.

205. Engle describes as 'strategic essentialism' the 'acceptance and deployment of static and essentialized notions of culture' as an advocacy strategy. She questions - and encourages activists and advocates to also question - whether the "the right to culture - and, perhaps human rights, more generally - is up to the task of the major economic and political restructuring that many advocates (if covertly) seem to seek'. Karen Engle, The Elusive Promise of Indigenous Development: Rights, Culture, Strategy (Duke University Press, 2010), 10.

206. Engle, 2009, above (n 201), 343 (emphasis in original), see also Engle, The Elusive Promise of Indigenous Development (n 201), Chs 6 and 7. 


\subsection{The 'subject' of indigenous rights}

The question of who is the 'subject' of rights accorded on the basis of indigeneity has been a vexed and unsettled question in international law. ${ }^{207}$ The problems associated with establishing a definition of 'indigenous peoples' (and by extension a distinction between 'indigenous' and other 'minority groups' $)^{208}$ have been resolved by a prevailing view 'that no formal universal definition of the term is necessary'. ${ }^{209}$ Instead various 'working' rather than 'fixed' or binding definitions have been developed, as well as the identification of some basic characteristics to aid the process of 'functional determinations' on a case-by-case basis. The most prominent of these, the Martinez Cobo definition, ${ }^{210}$ insists on 'self-definition' as the central principle ${ }^{211}$ but is also structured around the concept of 'historical continuity' with 'pre-invasion' or 'pre-colonial' societies. The International Law Association's 2012 Report lists several indicia that 'should be used in order to ascertain whether or not a given community may be considered as indigenous peoples'. These are: self-identification, historical continuity, special relationship with ancestral lands, distinctiveness, nondominance and perpetuation (or a desire to maintain and reproduce their distinct way of life). ${ }^{212}$

In 1989 ILO Convention 169, which applies both to 'tribal peoples' and those 'regarded as indigenous' provided the first legal definition of 'indigenous peoples' ${ }^{213}$ The 1994 Draft UN Declaration on Indigenous Peoples' Rights, included recognition

207. See for a discussion: Douglas E Sanders, 'Indigenous Peoples: Issues of Definition' (1999) 8(1) International Journal of Cultural Property 4.

208. Erica-Irene Daes and Asbjorn Eide, Working Paper on the Relationship and Distinction between the Rights of Persons Belonging to Minorities and those of Indigenous Peoples, Economic and Social Council, Commission on Human Rights, Sub-commission on the Promotion and Protection of Human Rights, E/CN.4/Sub.2/2000/10 (19 July 2000).

209. The Concept of Indigenous Peoples: Background Paper Prepared for the Secretariat of the Permanent Forum on Indigenous Issues (2004) PFII/2004/WS.1/3.

210. Jose R Martinez Cobo, Study on the Problem of Discrimination against Indigenous Populations, UN Doc E/CN.4/Sub.2/1986/7 and Add. 1-4 (1986).

211. Ibid [368]-[377].

212. International Law Association, Sofia Conference: Rights of Indigenous Peoples, Final Report (2012).

213. International Labour Organization (ILO), Indigenous and Tribal Peoples Convention (ILO No. 169), opened for signature 27 June 1989, 28 ILM 1382 (entered into force 5 September 1991). Article 1 states:

1. This Convention applies to:

(a) tribal peoples in independent countries whose social, cultural and economic conditions distinguish them from other sections of the national community, and whose status is regulated wholly or partially by their own customs or traditions or by special laws or regulations;

(b) peoples in independent countries who are regarded as indigenous on account of their descent from the populations which inhabited the country, or a geographical region to which the country belongs, at the time of conquest or colonization or the establishment of present state boundaries and who, irrespective of their legal status, retain some or all of their own social, economic, cultural and political institutions.

2. Self-identification as indigenous or tribal shall be regarded as a fundamental criterion for determining the groups to which the provisions of this Convention apply.

3. The use of the term peoples in this Convention shall not be construed as having any implications as regards the rights which may attach to the term under international law. 
of indigenous identity as self-defined. ${ }^{214}$ In 1997 at the 15 th session of the Working Group on the draft declaration on the rights of indigenous peoples, a conclusion was reached that a 'definition of indigenous peoples at the global level was not possible at that time' nor necessary for the purpose of a Declaration. ${ }^{215}$ The UNDRIP therefore does not include any explicit provisions defining the subject of the rights it enumerates, although self-identification is implied in the provision regarding community rules and membership. ${ }^{216}$

This flexible approach was celebrated by Erica-Irene Daes, long-term Chairperson of the UN Working Group on Indigenous Populations, on the basis that it was "not desirable or possible to arrive at a universal definition at the present time' ${ }^{217}$ Patrick Thornberry is similarly positive about the adaptive flexibility this enables, ${ }^{218}$ but also suggests that the 'characteristics' of this 'subject' of indigenous peoples' rights can be '... gleaned from the major specific texts on indigenous rights' ${ }^{219}$ He then writes that the characteristics of the indigenous subject 'gleaned' from the rights in the ILO Convention 169 are one with 'a specific social and cultural identity, customs, traditions and institutions', 'a distinctive relationship with lands and territories', 'subsistence economy and traditional activities', distinctive knowledges and technologies and languages. He concludes that 'instead of defining beneficiaries and then allocating rights, international law has often proceeded the other way around. Rights have been set out and continue to be developed in such a way that the contours of the communities appropriating them become clearer' ${ }^{220}$ His analysis points to the constructive nature of law and rights; namely that rights do not attach themselves to pre-constituted subjects, but rather rights enumeration is itself part of the process of constructing the subjects to which it refers. ${ }^{221}$ In contrast to a formalist approach, such a pragmatist approach that aims at 'describing' the subject of rights through a series of 'descriptive elements', effectively also constitutes the subject by reference to the rights it is entitled to. ${ }^{222}$ The approach generates a paradox, in that although self-identification as indigenous is a central indicia, peoples are most likely to be 'read' or 'recognized'

Note also that there was controversy around the use of the term 'peoples', which was only adopted after the Article 1(3) proviso to prevent it having any implications for a right to self-determination in international law was adopted.

214. Note in particular draft Article 8, Draft Declaration on the Rights of Indigenous Peoples (1994) UN Doc. E/CN.4/Sub.2/1994/2/Add.1.

215. See The Concept of Indigenous Peoples: Background Paper Prepared for the Secretariat of the Permanent Forum on Indigenous Issues, PFII/2004/WS.1/3 (2004).

216. See Articles 9 and Article 33, UNDRIP.

217. Erica-Irene A Daes, Report of the Working Group on Indigenous Populations on its Fifteenth Session. E/CN. 4/Sub 2/1997/19 (13 August 1997) [25].

218. Patrick Thornberry, Indigenous Peoples and Human Rights (Juris Publishing and Manchester University Press, 2002), 57.

219. Ibid, 51-2. See also Engle, 2010, above (n 201).

220. Ibid. See also Asbjørn Eide in the Working Paper on the Relationship and Distinction between the Rights of Persons Belonging to Minorities and those of Indigenous Peoples, E/CN.4/Sub.2/2000/10 (19 July 2000), who notes the difficulty in articulating a clear definition of indigeneity and writes that, 'on the contrary, in my view, being practical and realistic necessitates an approach that is purposive, and links the characteristics of groups to their aspirations and to the rights they are entitled to and realistically can exercise'.

221. Adil Hasan Khan, 'How is the Subject of International Indigenous Peoples' Rights Made? Or, When the Openness of Law Becomes its Other' (Paper presented at the 'Sculpting the Human' Association for the Study of Law, Culture and Humanities, Birkbeck, University of London, 2013). 222. Ibid. 
as indigenous if their claims for rights have a specific content. Kathleen Birrell therefore analyses the 'colonial schema' as 'compel[ling] a particular performance from the Indigenous subject, in order to appear before the law at all' and states that 'claims may be made via the performance of such identity'.223

Chris Tennant argues that in contrast to an earlier 'assimilationist' era (1945-1971) when the predominant representation of indigenous peoples was of the 'ignoble primitive' (ie uncivilized and living miserable lives requiring the 'practice of development ... to lift them out of their backwardness'), ${ }^{224}$ in the contemporary era these 'characteristics', which in earlier eras attempts had been made to erase, come to be considered as distinctive and deserving of protection. Tennant argues that after 1971 the dominant representation of indigenous peoples has been as 'noble' and as having that 'which the modern world most lacks, namely a close relationship to nature and the environment'. ${ }^{225} \mathrm{He}$ argues that the relationship of indigenous peoples to modernity is scripted in three key ways: (a) as victims of progress; (b) as supporting and legitimating a critique of process; and (c) as representing an aspiration to transcend modernity and progress through a 'return to the primitive'. ${ }^{226}$

This dominant representation of indigenous peoples therefore has become that of a 'cultural subject', whose primary characteristic is historically continuous 'cultural difference' and who are positioned both as 'keepers of our past, [and] custodians of our future'. ${ }^{227}$ The UNDRIP contains numerous articles seeking to protect this very 'cultural integrity', ${ }^{228}$ 'cultural difference ${ }^{229}$ and a set of ancient 'traditions' ${ }^{230}$ This is a culture whose 'difference' is what contributes to a state's 'cultural diversity' ${ }^{231}$ and whose 'traditional' status contributes towards augmenting humanity's various resources. ${ }^{232}$ However, this focus on cultural identity rather than the experience of colonialism as providing the key characteristics of indigeneity, produces a framework that is more orientated towards the protection and maintenance of certain characteristics deemed 'worthy' of human rights protections. That is, the focus is orientated towards the stabilization and protection of cultural difference, rather than the dismantling of persistent colonial relations that organize these representations of identity.

\subsection{Indigeneity as environmental stewardship}

As the 'importance of Indigenous involvement in environmental governance' ${ }^{233}$ is affirmed in more laws and policies, scholars have asserted a 'mutually supportive'

223. Kathleen Birrell, 'Indigeneity: Before and Beyond the Law', in Austin Sarat (ed), Special Issue Interdisciplinary Legal Studies: The Next Generation (Emerald, 2010), 219 at 223.

224. Chris Tennant, 'Indigenous Peoples, International Institutions, and the International Legal Literature from 1945-1993' (1994) 16(1) Human Rights Quarterly 1, 12.

225. Ibid, 12.

226. Ibid, 17.

227. See Erica-Irene Daes, 'Indigenous Peoples: Keepers of Our Past, Custodians of Our Future' (International Work Group for Indigenous Affairs, 2008).

228. UNDRIP, Article 8.

229. UNDRIP, Articles 14, 15, 16 and 34.

230. UNDRIP, Articles $11,12,13$ and 31.

231. For example, UNDRIP, Article 16(2).

232. For example, UNDRIP, Article 31.

233. Benjamin J Richardson, 'The Ties that Bind: Indigenous Peoples and Environmental Governance' (2008) 4 CLPE Research Paper Series, 3. 
relationship or 'presumptive connection' 234 between indigenous rights and environmental rights ${ }^{235}$ and an increasing interconnection between 'environmental justice' and the rights of indigenous peoples. ${ }^{236}$ The increasing intersection of environmental law and indigenous rights has the effect of producing a 'subject-position' of the 'ecological native ${ }^{237}$ who is posited as a steward of the environment on account of special ecological knowledge and nature-friendly lifestyle. ${ }^{238}$

There is a growing body of legal literature directed at, as Bradford Morse articulates, 'identify[ing] how asserting the recognized unique rights of indigenous peoples through international and domestic law forums can provide a foundation of environmental sustainability to be accepted as a paramount principle'. ${ }^{239}$ The Preamble of ILO Convention 169 calls attention to 'the distinctive contributions of indigenous and tribal peoples to the cultural diversity and social and ecological harmony of humankind' ${ }^{240}$ The Convention further affirms that the 'rights of the peoples concerned to the natural resources pertaining to their lands shall be specially safeguarded', especially rights 'to participate in the use, management and conservation of these resources'. ${ }^{241}$ Similarly, Article 25 of the UNDRIP protects 'the right to maintain and strengthen their distinctive spiritual relationship with their ... lands ... [and] other resources and to uphold their responsibilities to future generations in this regard'. ${ }^{242}$

Similar articulations emerge from the field of international environmental law, with the 1987 Brundtland Commission positioning indigenous communities as a 'link' with humanity's 'ancient origins', who as 'repositories of traditional knowledge' and 'traditional skills in sustainably managing very complex ecological systems' need to be recognized and protected. ${ }^{243}$ Principle 22 of the Rio Declaration celebrates the 'vital role' indigenous people and local communities have in environmental management due to their 'knowledge and traditional practices' and 'their identity, culture and interests', which should be recognized and supported in order to 'enable their effective participation in sustainable development'. ${ }^{244}$ Similarly, although conservation had traditionally followed a 'people-free parks' approach, by the late 1990s communities had become 'the locus of conservationist thinking' having been 'found' as

234. Cherie Metcalf, 'Indigenous Rights and the Environment: Evolving International Law' (2003-2004) 35(1) Ottawa Law Review 101, 107.

235. Klaus Bosselmann, 'The Right to Self-determination and International Environmental Law: An Intergrative Approach' (1997) 1 New Zealand Journal of Environmental Law 1.

236. Laura Westra, Environmental Justice and the Rights of Indigneous Peoples: International and Domestic Legal Perspectives (Earthscan, 2008).

237. See for example, Astrid Ulloa, The Ecological Native: Indigenous Peoples' Movements and Eco-Governmentality in Colombia (Routledge, 2005).

238. See also Alcida Rita Ramos, 'The Hyperreal Indian' (1994) 14(2) Critique of Anthropology 153 .

239. Bradford Morse, 'Indigenous Rights as a Mechanism to Promote Sustainability', in Laura Westra, Klaus Bosselmann and Richard Westra (eds), Reconciling Human Existence with Ecological Integrity (Earthscan, 2008) 160.

240. ILO Convention 169, Preamble, my emphasis.

241. ILO Convention 169, Article 15(1).

242. UNDRIP, Article 25 (my emphasis).

243. Brundtland Commission Report, Our Common Future. World Commission on Environment and Development (Cambridge University Press, 1987), 114-15.

244. See also Convention on Biological Diversity, 1992, Article 8 (j). 
relevant subjects by international and national development organizations, conservation groups, and philanthropic organizations. ${ }^{245}$ Twenty years later the Rio+20 outcome document stressed the 'importance of the participation of indigenous peoples in the achievement of sustainable development' and of the UNDRIP in the 'context of global, regional, national and subnational implementation of sustainable development strategies'.246

While there are many examples of environmental/indigenous alliances, knotting this nexus too tightly disregards the complexities and contradictions that arise in different contexts. ${ }^{247}$ Moreover, depicting indigenous and environmental rights as 'mutually supportive' can dangerously instrumentalize indigenous rights, authorizing rights on the basis that they are an 'effective strategy' for the protection of the global environment. ${ }^{248}$ What could emerge is what Li calls a 'compromise agreement' that 'social groups that are unique or different should have their knowledge and rights respected if and when it is instrumental to conservation objectives' in which 'only specific kinds of knowledge are relevant' and 'rights are conditional upon performance'. ${ }^{249}$ Moreover, invocations of 'the right to environmental self-determination of indigenous peoples' ${ }^{250}$ risks narrowing understandings of indigeneity to that of the 'noble savage', a construction that has been heavily criticized for its 'green imperialism' ${ }^{251}$ Moreover, such representations often posit an imagined ideal that 'few indigenous groups can live up to'. ${ }^{252}$ Engle argues that a 'dark side' or 'unintended consequence' of the 'concept of culture as territory' is that it can operate as a tool for distinguishing who is indigenous and deserving of protection. She writes:

That is, if real Indians care about the land, those who are seen not to care for it properly might be restricted in their uses of it, or denied rights to it altogether. Second, given that the object of protection is the land, its stewardship sometimes takes priority over the autonomy of indigenous peoples. ${ }^{253}$

She writes that an 'even more serious consequence to the pursuit of a political and legal strategy based on a special relationship to land' can be that '[w]hen they do not behave towards the land in the idealized manner that has come to be expected of them, these groups might cease to be considered real Indians' ${ }^{254}$ She shows how, in some cases, communities have been required to 'learn' sustainable ways of

245. Arun Agrawal and Clark C Gibson, 'Enchantment and Disenchantment: The Role of Community in Natural Resource Conservation' (1999) 27(4) World Development 629, 631.

246. The Future We Want, GA Res 66/288 (2012), [49]. Indigenous peoples are also mentioned at numerous other points in the document, including participation [43], the 'green economy' [58 (j)], partnerships [71], 'traditional' knowledges [197], mountains [211], education [229], women [238] and forests [193].

247. For a discussion of some of these complexities in an Australian conservation project see: Timothy Neale, 'Contest and Consent: The Legacy of the Wild Rivers Act 2005 (QLD)' (2012) 8(3) Indigenous Law Bulletin 6.

248. Cf Bosselmann, above (n 235), 1.

249. Tania Murray Li, 'Masyarakat Adat, Difference, and the Limits of Recognition in Indonesia's Forest Zone' (2001) 35(3) Modern Asian Studies 645, 657.

250. Bosselmann, above (n 235), 1.

251. Larry Lohmann, 'Green Orientalism' (The Corner House, 1993), see also Ramos, above (n 238), 1994.

252. Engle, 2009, above (n 201), 343.

253. Engle, The Elusive Promise, above (n 201), 168.

254. Ibid, 170 . 
living on the land, 'attributed to indigenous origins and practices', in order to claim their collective ownership of the land. ${ }^{255}$

\subsection{Safeguard policies and determining indigeneity}

This question of how peoples are read is of particular relevance when considering that the application of safeguard policies often requires case-by-case determination of whether a project affects 'indigenous peoples' by 'legal experts' and 'technocrats'. The World Bank's policies regarding 'Indigenous Peoples' - Operational Directive 4.20 (1991), Operational Policy 4.10 (2005) and the proposed Environmental and Social Safeguard 7 (2014) - also do not provide a definition of 'indigenous peoples' but list characteristics for the purpose of identification. ${ }^{256}$ OD 4.20 and OP 4.10 state that such a determination requires a 'technical judgment' by Bank officials 'on the ground' with the assistance of other 'experts', namely 'qualified social scientists' ${ }^{257}$ The draft consultation safeguard policy, which has been heavily criticized ${ }^{258}$ by human rights groups, simply notes that 'following a determination by the World Bank that Indigenous peoples are present in, or have collective attachment to the project areas', safeguard requirements may apply. ${ }^{259}$

The guidelines on FPIC in REDD+ extend the principles of FPIC to apply to indigenous peoples but also local communities. For example the UN-REDD Programme guidelines states that consent should also be sought from 'other local communities that have customary and/or legal rights to the territory/resources that will be affected by the project/activity in question'. ${ }^{260}$ Similarly, the RECOFTC guidelines states that '[a] proposed REDD+ project should map all tenure claims and a process to respect the right to FPIC should be developed to engage all communities whose lands and forests overlap with the proposed REDD+ project'. ${ }^{261}$ In a discussion on REDD+ safeguards by ClientEarth and UK Aid the authors write that "local communities" is a broad concept that often goes undefined and unrecognized, but could be given an equally flexible interpretation as "indigenous peoples". 262 They cite a 2011 Expert Group under the Convention of Biological Diversity that found that for the purposes of Article $8(\mathrm{j})$ of that Convention, the term 'local communities' was not distinguished from the term 'indigenous peoples' and moreover that many communities can be

255. Ibid, 173.

256. World Bank, Operational Directive 4.20: Indigenous Peoples (September 1991); World Bank, Operational Policy 4.10: Indigenous Peoples (July 2005), <http://web.worldbank.org/ WBSITE/EXTERNAL/PROJECTS/EXTPOLICIES/EXTOPMANUAL/0,, contentMDK: 20553653 menuPK:4564185 pagePK:64709096 piPK:64709108 theSitePK:502184,00. html> accessed 10 February 2015; Proposed Social and Environmental Safeguard 7 (ESS7), $<$ https://consultations.worldbank.org/Data/hub/files/consultation-template/review-and-updateworld-bank-safeguard-policies/en/materials/proposed_environmental_and_social_standards__ess7.pdf>.

257. The Operational Policy 4.10 [8].

258. Forest Peoples' Program 'Significant Concerns with the Proposed World Bank Safeguards for Indigenous Peoples', <www.safeguardcomments.org >.

259. ESS7 [8].

260. UN-REDD Programme, Guidelines on FPIC (2011), 13.

261. Anderson, above (n 112), 32.

262. D Ray et al., 'A Guide to Understanding and Implementing the UNFCCC REDD+ Safeguards' (Client Earth, 2013), 40. 
considered both 'local' and 'traditional' and in some cases include people of indigenous descent. ${ }^{263}$ The guide on safeguards further notes that specifically in the African context the term 'local community' may be considered more appropriate than 'indigenous peoples' and notes the South African Development Community (SADC) Protocol on Forestry which defines 'local communities' as '[a] coherent, social group of persons with interests or rights related to forest or forest resources, in a particular area, which the persons hold or exercise communally in terms of an agreement, custom or law'. ${ }^{264}$ However, as there are no international legal instruments addressing specifically the rights of 'local communities', the authors of the guide further note that the 'legal status of local communities and enjoyment of collective rights may vary according to national circumstances'. ${ }^{265}$

The discussion so far has identified that safeguarding mechanisms demand certain attributes to be displayed or certain 'subject-positions' to be performed in order for peoples to be interpreted as indigenous. The tensions that these requirements to enact 'ecological stewardship' create are not resolved by the extension of REDD+ safeguards to 'local communities' who are imagined in similar terms. Rather, I suggest the effect of these requirements to perform a specific 'subject-position' in order to claim rights is to make it difficult for forest peoples in the REDD+ context to be read as 'indigenous' (or even 'local' or 'traditional') and simultaneously as not consenting. This presents clear challenges for those asserting indigeneity and resisting REDD+ projects.

\subsection{Interpreting free, prior and informed consent}

In this section, I discuss some recent interpretations of FPIC that indicate the protection such processes offer short of the 'veto' right often imagined in discussion of REDD+ safeguards. Although the best practice manuals on FPIC stress a right to withhold or withdraw consent to REDD+ project, most legal interpretations stress that the UNDRIP does not establish a general right to veto in favour of indigenous communities. ${ }^{266}$ The UNDRIP does not impose an obligation on states to obtain the consent of indigenous peoples; rather, as Engle describes, the obligation is to 'consult and cooperate in good faith with the indigenous peoples concerned through their own representative institutions in order to obtain their free, and informed consent, prior to the approval of any projects affecting their lands, territories and other resources' ${ }^{267}$ In contrast to the 1993 draft of the declaration where consent was a requirement, in the UNDRIP consent is articulated as a goal.

In a series of reports to the Human Rights Council, the then Special Rapporteur on the Rights of Indigenous Peoples, James Anaya, further defined but also narrowed the scope of FPIC. In a 2009 report he outlined the 'duty to consult' and specifically argued against any construction of Article 19 of the UNDRIP as according indigenous

263. Ibid, see also Expert Group Meeting of Local Community Representatives within the Context of Article 8(j) and Related Provisions of the Convention on Biological Diversity (Montreal, 7 July 2011), Guidance for Discussions Concerning Local Communities within the Context of the Convention on Biological Diversity, UNEP/CBD/AHEG/LCR/1/2, 1.

264. Ray et al., above (n 262), 41; South African Development Community Protocol on Forestry, 3 October 2002, entered into force 17 July 2009, Article 2(1).

265. Ray et al., ibid, 41.

266. See the discussion in ILA, 'Final Report' (2012), 3-7.

267. Engle, 2011, above (n 201), 157, fn 56 (original emphasis). 
peoples a "“veto power" over decisions that affect them' ${ }^{268}$ In his interpretation, a framing of this requirement as a 'veto power' that could be wielded to stop development projects is 'not in line with the spirit or character of the principles of consultation and consent' as developed in human rights jurisprudence and incorporated into the Declaration. ${ }^{269}$ Rather, these provisions are designed to 'build dialogue' and 'work in good faith towards consensus' in order to achieve 'mutually satisfactory agreements'. ${ }^{270} \mathrm{He}$ concludes that:

The principle that indigenous consent should be the objective of consultation does not mean that obtaining consent is an absolute requirement for all situations. In all cases, what fundamentally matters is that a good faith effort by the State is made to achieve agreement. Indigenous peoples, as well, should seek in good faith to reach consensus on proposed measures and avoid inflexible positions when the proposed measure is based on legitimate public interests. ${ }^{271}$

In a 2012 report, Anaya considered the 'scope of the duty' to seek FPIC in relation to extractive industries. He advanced an interpretation in which neither consultation or consent are an 'an end in itself' or 'stand-alone rights' but rather a 'means for the exercise of indigenous peoples' substantive rights' that 'supplements and helps effectuate substantive rights' such as the right to property. ${ }^{272}$ Having positioned FPIC as a procedural right to ensure the protection of substantive rights, he then argues that an 'understanding of the underlying substantive rights and the potential impact on these rights' must be the 'starting point' for 'resolving the many questions' that arise in relation to FPIC. ${ }^{273}$ This interpretation would suggest that if an underlying substantive right, such as the right to property, culture or to manage natural resources, was not implicated by a decision or the impact on it was minimal, the procedural obligations to seek consent might also be lessened. While Anaya does not discuss FPIC in the REDD+ context, such an interpretation would suggest that for projects that sought to formalize land rights and engage community participation, FPIC might be only minimally engaged, even if the project might preclude people living in and around forests from pursuing other potential ('less authentic') commercial uses of the land than they might otherwise choose.

In a further 2013 report, Anaya discusses the scope of this duty and the "narrow scope of permissible exceptions to the general rule' (again in relation to extractive industries). ${ }^{274} \mathrm{He}$ argues that consent may not be required where 'it can be

268. James Anaya, Promotion and Protection of all Human Rights, Civil, Political, Economic, Social and Cultural Rights, Including the Right to Development: Report of the Special Rapporteur on the Situation of Human Rights and Fundamental Freedoms of Indigenous Peoples, James Anaya, Human Rights Council, 12th session, A/HRC/12/34 (15 July 2009) [36]-[57]. Note, this report and its conclusions are endorsed in the ILA, 'Final Report', (2012) 3-7. However, they also stated that 'there are particular cases with respect to which international institutions have recognized the existence of a full veto right in favour of indigenous peoples in relation to specific kinds of measures which may effect them' (4).

269. Ibid [48].

270. Ibid [49].

271. Ibid [66] (my emphasis).

272. James Anaya, Report of the Special Rapporteur on the Rights of Indigenous Peoples, James Anaya, Human Rights Council, 21st session, A/HRC/21/47 (6 July 2012) [49].

273. Ibid [53].

274. James Anaya, Report of the Special Rapporteur on the Rights of Indigenous Peoples, James Anaya: Extractive Industries and Indigenous Peoples, Human Rights Council, 24th session, A/HRC/24/41 (1 July 2013). 
conclusively established that the activities will not substantially affect indigenous peoples in the exercise of any of their substantive rights in relation to the land and resources within their territories' or where the activity would 'only impose such limitations on indigenous peoples' substantive rights as are permissible within certain narrow bounds established by international human rights law' ${ }^{275} \mathrm{He}$ goes on to explore how human rights law allows certain limitations on the exercise of rights to be imposed by states, provided these limitations have a valid public purpose and comply with standards of necessity and proportionality. ${ }^{276} \mathrm{He}$ dismisses the argument made by some states that the 'valid public purpose' test grants them the power to expropriate indigenous property interests to order to get access to subsurface resources over which they claim ownership, cautioning that 'mere commercial interests' or 'revenue-raising objectives', especially when primarily for private gain, should not be considered a valid public purpose. ${ }^{277}$ It is however arguable whether in the REDD+ context, an assessment of 'valid public purpose' would be more likely to be favourable, given the designation of forest carbon sequestration as a global matter of 'common concern'.

In contrast to Anaya's analysis, the best practice guides introduced at the beginning of this section on FPIC in REDD+, stress that right to refuse consent is 'fundamental' to FPIC and should be supported by project implementers. However, Patrick Anderson, author of the guide prepared for The Centre for People and Forests, suggests that a refusal does not end the process of seeking consent, as both 'giving and withholding of consent is time-specific - both can be re-visited and revised'. ${ }^{278}$

The obligation of FPIC as interpreted above, clearly remains an incredibly important procedural right in situations where REDD+ projects might affect underlying substantive rights, for example by displacing peoples or restricting access to cultural sites or activities. In the face of many REDD+ projects on the ground that continue to exclude peoples' participation, within a wider landscape where extractive industries, logging and plantations continue to wreak destruction, there can be a real utility in a strategic deployment of cultural rights to realize greater inclusion in and benefit sharing from forest carbon offset projects. ${ }^{279}$ I support communities' rights to oppose or 'veto' projects that they believe will have negative social impacts; however, the interpretation above suggests that processes of consultation towards FPIC might have less utility in resisting REDD+ schemes that are fully participatory and continue to allow for indigenous 'cultural rights' of ecological management, even where they foreclose the ability of peoples to determine other (more commercial or less 'authentic') future trajectories.

\subsection{The productive effects of FPIC}

The above discussion suggests the need to ask different questions about the work that processes of FPIC are doing on the ground. Although further empirical work would be necessary to substantiate this hypothesis, I suggest that FPIC processes should be

275. Ibid [31].

276. Ibid [32].

277. Ibid [35].

278. Anderson, 2011, above (n 112), 26.

279. I have participated in advocacy that stressed FPIC and participation as preconditions for REDD+ projects: Pearse and Dehm, above (n 12). 
understood as directed towards facilitating the incorporation of communities in REDD+ projects. That is, an important future research question concerns the function that the articulation of consent plays, especially when contracts are understood not just as instruments that allocate pre-existing rights to pre-existing subjects, but as performative, in that they bring into being and are constitutive of the 'self' and the concept of 'property' they presuppose. 280

In this best-practice manual the requirement that a community be 'informed' about a project by its proponent, morphs into an implicit requirement that the community has to demonstrate the capacity 'to consider the project or program' and 'to develop a clear understanding [of] REDD+ implementations', ${ }^{281}$ as assessed by the external criteria and from the external perspective of the validating body. In this way, an obligation on project proponents to provide information becomes the means by which ongoing socialization in the case of refusal can be justified. If such 'capacity' is not deemed to be present, then '[a]dequate resources will also be needed by rights holders to build up their capacity to consider the project or program', including 'appropriate training and skills development' 282 which 'should continue throughout the life of the project'. ${ }^{283}$ Moreover, the assessment of the 'capacity' of a community to understand a project becomes the means for an external assessment of the rationality of local decision-making processes and epistemological evaluations and the justification of interventions to 'improve' these.

The manual outlines how the question of 'capacity' includes particular modes of internal governance and decision-making processes, modes of communicating, financial literacy, skill in particular ways of knowing (mapping) and engaging with world, ${ }^{284}$ as well as a particular relationship with the monetary economy, including the 'capacity to manage funds in a transparent and accountable manner' 285 and also including accounting proficiency and prudent financial planning. ${ }^{286}$ While a collective's right to 'use their own decision-making institutions rather than an imposed system, ${ }^{287}$ is explicitly affirmed, this right to internal self-governance is also tempered by external expectations of what constitutes proper 'good governance' or 'representation', especially where 'traditional institutions may be seen to be in conflict with international notions and expectations of "representation" and the need to include women, youth and marginalized people in decision-making'. ${ }^{288}$ The articulation of consent is thereby also the enactment of what it demonstrates; a collective subjectivity that is free, self-governing and selfpossessed and therefore suitably responsible to commit itself. In this sense the articulation of consent, in a situation where those consenting could not do otherwise, is a performance and articulation that demonstrates a collective responsibilization as an accountable, contractual subject, in the present and into the future.

280. See David Gray Carlson, 'How to Do Things with Hegel' (1999-2000) 78 Texas Law Review 1377; also Angela Mitropoulos, Contract and Contagion: from Biopolitics to Oikonomia (Minor Compositions, 2012), 19-49.

281. Anderson, above (n 112).

282. Ibid.

283. Ibid, 45 .

284. Ibid.

285. Ibid.

286. Ibid, 46.

287. Ibid, 35 .

288. Ibid. 


\section{DISCUSSION}

The logic of the offset, in which pockets of sustainable or regenerative activities in the global South legitimates additional polluting activities in the global North, reappears again in the logic of cultural difference protected by rights in REDD+. REDD+, if implemented as 'best-practice' models would envision, could similarly support the protection of small pockets of cultural rights that are understood as both distinctive from and redemptive of modernity. Lost in this focus on rights in REDD+ are both the distributional questions about what obligations are imposed on whom to address climate change, but also the need to push for broader systemic - cultural and ecological - change that rejects the substitutions of the offset economy.

In the context of global climate mitigation, the focus on the 'inherent' (or forcefully learned) capacity of the indigenous ecological subject as 'leaders in the struggle to protect and rehabilitate the environment of our shared planet' ${ }^{289}$ can operate perversely to undermine the 'responsibility principle' articulated in the principle of "common but differentiated responsibilities' central to the UNFCCC. ${ }^{290}$ Instead of addressing questions of historical and ongoing responsibility for GHG emissions, these processes of recognition are directed towards responsibilizing forest peoples to be a certain type of subject, who by performing authenticity can be trusted to protect forests. In REDD+ projects, this construction of indigenous subjectivity as ecological stewardship can lead to a problematic imagination of the 'ecological' subject who would voluntarily deploy traditional knowledges and undertake conservation activities to protect ecosystem services for the 'common good', in ways that displace the social responsibility that global elites have to reduce their oversized carbon footprints.

Climate change presents a global challenge that will require everyone to take some form of action to promote mitigation and adaptation. In this sense, it is inevitable that people globally will need to become responsibilized to change their behaviours and internalize these changes. The critique articulated in this article, however, is directed to the uneven way that market-based climate governance compels climate action from different individuals and groups. This article has highlighted how carbon markets have allowed those most responsible for the climate crisis to evade certain forms of action, while compelling action from others who have a minimal carbon footprint. In this way, the focus on the capacity and purported cultural disposition of indigenous peoples to take climate mitigation in REDD+ promotes irresponsibility, by displacing the question of responsibility for carbon emissions and allowing those with the greatest historical responsibility for climate change to keep polluting. As such, REDD+ promotes an obfuscation of international responsibility alongside the responsibilization of local actors.

The paradoxes of these processes are perhaps experienced most acutely by peoples living in and around forest areas, who continue to face a range of livelihood pressures, including from highly unsustainable palm oil, timber and mining projects. Grassroots organizations representing people living on the site of the KFCP project have released a series of statements and an open letter released to a pre-Copenhagen

289. Morse, above (n 239).

290. UNFCCC, Article 3(1) sets out the following principles: 'The Parties should protect the climate system for the benefit of present and future generations of humankind, on the basis of equity and in accordance with their common but differentiated responsibilities and respective capabilities'. 
UNFCCC meeting (2009) ${ }^{291}$ and coinciding with the Cancun $(2010)^{292}$ and the Rio +20 (2012) meetings. ${ }^{293}$ In these letters they describe REDD+ and the green economy as 'a new face of capitalism in the shape of ecological imperialism' that does not operate as a climate solution. ${ }^{294}$ They also however describe their own grassroots work to rehabilitate the area through revegetation and ongoing resistance to palm oil and mining expansion in the area, noting ' $[w]$ e have become ... part of the solution to climate change'. ${ }^{295}$ Yet simultaneously, they speak of how their initiatives 'have not been regarded as an important contribution in the global solution to climate change'. ${ }^{296}$ There is, they note, no global interest in learning from ' $[\mathrm{t}]$ he initiatives of people throughout the world [that] constitute a model for managing the environment in a way that could save our families and all the inhabitants of the earth'. ${ }^{297}$ Alongside the marginalization of these environmental knowledges they speak of the injustice that arises '[w]hen developed countries don't want to stop their own carbon emissions, [and] those who are most innocent have to shoulder the entire burden'. ${ }^{298}$

\section{CONCLUSION}

This article has analysed the discourses around and frameworks of safeguards in REDD+. It has traced the convergence in discussions around REDD+ that have marginalized questions concerning the desirability of such schemes and have focused instead on their mode of implementation and ways of mitigating potential risks and promoting benefits. Subsequently, this article has examined in more detail discussions about risks and benefits regarding both tenure reform and processes towards FPIC. The argument here identified is that the contemporary logic of 'expulsion', ${ }^{299}$ which hangs as a spectre over REDD+, is not the only logic at play in REDD+ implementation. Indeed, I have argued that the problem of the social in REDD+ is better understood as 'fixing people in place' and transforming forest peoples into environmental service providers of the 'green economy'. Such intensive integration in the globalized 'green economy' carries with it significant risks, especially given massive price fluctuation in international carbon markets, and the fact that through REDD+ former livelihood activities or subsistence practices become prohibited.

The present article positions both tenure reform and processes towards FPIC as safeguards that could facilitate either resistance to REDD+ schemes or greater disciplinary

291. Aliansi Rakyat Pengelola Gambut (ARPAG) Central Kalimantan, Open Letter of APARG for International Meeting UNFCCC Bangkok 2009, Local Peoples' Initiative, Solidarity to Save Peatland Ecology in Central Kalimantan-Indonesia, 2008, copy on file with author.

292. Yayasan Petak Danim Kalimantan Tengan, Central Kalimantan Peatland Charter: Peat Resource is our Life Blood and Breath, for COP16, Cancun Mexico 2010, 2010, copy on file with author.

293. Petak Danum Kalimantan Tengah, Our Land is not a Carbon Toilet for Dirty Industries of Developed Countries, 2012, copy on file with author.

294. Ibid (my emphasis).

295. Yayasan Petak Danim Kalimantan Tengan, Central Kalimantan Peatland Charter: Peat Resource is our Life Blood and Breath, for COP16, Cancun Mexico 2010, 2010, copy on file with author.

296. Ibid.

297. Ibid.

298. Ibid.

299. Sassen, 2014, above (n 137). 
inclusion in REDD+ projects. It examined both in detail to explore how the potential for contesting REDD+ in both these safeguards was neutralized and restricted in particular ways. The analysis in this article suggests that while such mechanisms might assist communities in realizing their interests within REDD+ projects and help promote better REDD+ project implementation, they offer only a limited possibility for resisting or opposing REDD+. Promoting more inclusive, participatory and rights-based models of REDD+ implementation can make real material differences for people who may have long histories of economic, social and political marginalization. In pointing to the potential limitations of these safeguards, I in no way want to dismiss the very important struggles for tenure reform, 'rights before REDD+' and free, prior and informed consent that have been taken up by communities and advocates concerned about the impacts of REDD+ projects on their livelihoods. My intention is rather to draw attention to how 'neoliberalism incorporates techniques that domesticate and contain dissent within (certain) parameters', ${ }^{300}$ and moreover, how practices of dissent and resistance may also 'be subject to entanglement within the very processes they seek to contest'.301

Finally, this article has highlighted how realizing rights in REDD+ does not address the broader distributional questions raised by carbon markets and their allocations of differentiated privileges, obligations and responsibilities. As such, I suggest that the schema of rights recognition operative in REDD+ is made dangerously conditional on forest peoples taking action in the name of a global 'common concern', even as the responsibility of those with the greatest historical greenhouse gas emissions is obfuscated.

300. Ibid.

301. Lara Montesinos Coleman, 'The Making of Docile Dissent: Neoliberalism and Resistance in Columbia and Beyond' (2013) 7 International Political Sociology 170, 170. 